\title{
Lead and copper-induced hormetic effect and toxicity mechanisms in lettuce (Lactuca sativa L.) grown in a contaminated soil
}

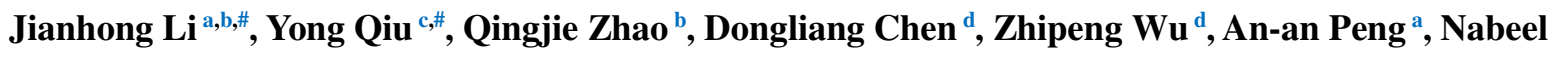 Khan Niazi $^{\text {e,f }}$, Lukáš Trakal ${ }^{\mathrm{g}}$, Ruben Sakrabani ${ }^{\text {h }}$, Bin Gao ${ }^{\mathrm{i}}$, Hailong Wang ${ }^{\mathrm{a}, \mathrm{j}, *}$, Weidong Wu ${ }^{\text {b,* }}$}

${ }^{a}$ Biochar Engineering Technology Research Center of Guangdong Province, School of Environmental and Chemical Engineering, Foshan University, Foshan, Guangdong 528000, China

${ }^{\mathrm{b}}$ College of Tropical Crops, Hainan University, Haikou, Hainan 570228, China

${ }^{\mathrm{c}}$ College of Oceanology and Food Science, Quanzhou Normal University, Quanzhou, Fujian 362000, China

${ }^{\mathrm{d}}$ Institute of High Energy Physics, Chinese Academy of Sciences, Beijing 100039, China

e Institute of Soil and Environmental Sciences, University of Agriculture Faisalabad, Faisalabad 38040, Pakistan

${ }^{\mathrm{f}}$ School of Civil Engineering and Surveying, University of Southern Queensland, Toowoomba 4350 Queensland, Australia

${ }^{\mathrm{g}}$ Department of Environmental Geosciences, Faculty of Environmental Sciences, Czech University of Life Sciences Prague, Kamýcká 129, 16500, Praha 6, Suchdol, Czech Republic

${ }^{\text {h }}$ School of Water, Energy \& Environment, Cranfield University, Cranfield, MK45 4DT Bedfordshire, United Kingdom

${ }^{\mathrm{i}}$ Department of Agricultural and Biological Engineering, University of Florida, Gainesville, FL, USA

${ }^{\mathrm{j}}$ Key Laboratory of Soil Contamination Bioremediation of Zhejiang Province, Zhejiang A\&F University, Hangzhou, Zhejiang 311300, China

\# Jianhong Li and Yong Qiu contributed equally to this work and should be considered co-first authors.

* Corresponding authors. E-mail addresses: hailong.wang@fosu.edu.cn (H. Wang), wdwu@ @ainanu.edu.cn (W. $\mathrm{Wu})$. 


\begin{abstract}
Lead $(\mathrm{Pb})$ and copper $(\mathrm{Cu})$ contamination seriously threatens agricultural production and food safety. This study aims to investigate $\mathrm{Pb}$ and $\mathrm{Cu}$ induced hormetic effect and toxicity mechanisms in lettuce (Lactuca sativa $\mathrm{L}$.) and establish reliable empirical models of potentially toxic elements (PTEs) transfer in the soil-plant system. The content and distribution of $\mathrm{Pb}$ and $\mathrm{Cu}$ at subcellular levels in lettuce plants were examined using inductively coupled plasma-mass spectrometry, differential centrifugation and micro-X-ray fluorescence spectroscopy. The PTE-loaded capacity of $\mathrm{Pb}$ that ensures food safety was lower than that of $\mathrm{Cu}$ in the studied soil, but the PTEloaded capacity of $\mathrm{Pb}$ that limits yield was higher than that of $\mathrm{Cu}$. Lead in lettuce roots mainly accumulated in the cell wall (41\%), while $\mathrm{Cu}$ mainly accumulated in the vacuoles $(46 \%)$. The $\mathrm{Pb}$ and $\mathrm{Cu}$ were primarily distributed in the radicle of lettuce seeds under severe PTE stress, resulting in no seed development. Iron plaque formed on the root surface of lettuce seedlings and sequestered $\mathrm{Pb}$ and $\mathrm{Cu}$ via chelation. At the same concentration, lettuce was less tolerant to $\mathrm{Cu}$ in contaminated soil than $\mathrm{Pb}$ due to the higher activity of $\mathrm{Cu}$ ions in the soil. Lead was more phytotoxic to lettuce than $\mathrm{Cu}$, however, since the radicle emerged from the seed under severe $\mathrm{Cu}$ levels, while it did not protrude under severe $\mathrm{Pb}$ levels. The potentially damaging effect of $\mathrm{Pb}$ in the visually healthy lettuce appeared to be higher than that of $\mathrm{Cu}$ under the same soil contamination level.
\end{abstract}

Keywords: Potentially toxic element; soil contamination; PTE-loaded capacity; safe lettuce production; $\mu$-XRF

\begin{abstract}
Abbreviations
ICP-MS, inductively coupled plasma-mass spectrometry; PTE, potentially toxic element; PCEFS, PTE-loaded capacity that ensures food safety; PCLY, PTE-loaded capacity that limits yield; PCKS, PTE-loaded capacity that kills seed; $\mu$-XRF, micro X-ray fluorescence spectroscopy
\end{abstract}

\title{
1. Introduction
}


Contamination of soils with potentially toxic elements (PTEs) has led to severe environmental and health problems globally (Mackay et al., 2013; Cai et al., 2019; Fang et al., 2020). It has been reported that the local children in smelter-affected areas around a copper smelter in Hubei province, China were likely under high health risks, up to 30.25 times higher than the acceptable healthy level, and most of the health risks were resulted from PTEs exposure through ingestion of food crops (Cai et al., 2019). A further risk factor for PTEs is their higher toxicity in animals, including humans, than in plants (DEFRA, 2002). Therefore, studying the potential risk of PTEs in crops is vitally important in order to reduce the intake of PTEs.

Recent toxicology and risk assessment studies revealed PTE-induced hormesis in plants, i.e., stimulation in plant growth at low-doses while suppression at high-doses, which is called hormetic effect (Shahid et al., 2019). The biomass of plants can be increased by exposure to PTEs before reaching the threshold that would cause a negative effect (Yang et al., 2016; Shahid et al., 2019). It is assumed that human exposure to PTEs below the levels specified in official standards carries minimal human health risk (DEFRA, 2002). Since the concentration of PTEs in plants is not visibly discernible, humans may ingest potentially harmful levels of PTEs when consuming visually healthy plants (Ferri et al., 2015; Yuan et al., 2019; Bandara et al., 2020). Therefore, in order to protect consumers against elevated exposure to PTEs through the ingestion of visually healthy crops, PTEinduced hormetic effect for crops and their mechanisms, as well as information concerning the relationship between PTE contamination levels and safe food production, e.g., the exact PTE levels that meet food safety standards or lead to a decline in crop yields should be explored (e.g., Chen et al., 2020; Xia et al., 2020). Investigating the toxicity and accumulation of PTEs in crops and unraveling the tolerance mechanism of crops in soil-plant systems can help efforts to reduce the risk of PTE intake from visually healthy crops.

Mwamba et al. (2016) reported that the efficiency of different alleviation strategies could vary against various PTEs (with different elemental characteristics) toxicity to plants. The distribution of PTEs at subcellular level 
could directly present the level of metal intra-cellular activity, thus the extent of potential toxicity to plant (van Assche and Clijsters, 1990). Determining the subcellular distribution of PTEs and their localization in plant tissues can provide helpful information on PTE tolerance of plants and toxicity mechanisms of PTE to plants (Sokolova et al., 2005; Wu et al., 2013; Sun et al., 2018). Synchrotron radiation-based X-ray fluorescence spectroscopy ( $\mu$ $\mathrm{XRF}$ ) and X-ray absorption fine structure (XAFS) spectroscopy are often used to demonstrate remediation effects on PTE pollution (Wu et al., 2017; Li et al., 2019a, b) and the accumulation mechanisms of PTEs in plants (Lu et al., 2017b). Some studies have revealed the translocation of PTEs in plants using differential centrifugation, inductively coupled plasma-mass spectrometry (ICP-MS) and $\mu$-XRF spectroscopy (Wu et al., 2013; Sun and Luo, 2018). The $\mu$-XRF method can be effectively used to visualize the distribution of mineral elements in microregions of plant organs ( $\mathrm{Lu}$ et al., 2017b). Using $\mu$-XRF spectroscopy, Lu et al. (2017b) reported a clear preferential localization of copper $(\mathrm{Cu})$ in the meristematic zone in the root tips of rice, compared with the elongation zone. In response to lead $(\mathrm{Pb})$ and chromium $(\mathrm{Cr})$ stress, $\mu$-XRF determined that $\mathrm{Pb}$ and $\mathrm{Cr}$ were mainly distributed in the cortex of the root of pak choi (Brassica chinensis L.), where they restrict transport from the root to the stem (Wu et al., 2013).

Lettuce (Lactuca sativa L.) is a PTEs-accumulating plant (Cobb et al., 2000) and is recommended for standard toxicity tests (e.g., ISO/CD 17126; ISO, 1995). Lettuce is one of the most consumed leafy vegetables (Kim et al., 2016). The lettuce grown in the United States alone has been valued at over 2.4 billion USD (NAAS, 2015). Lettuce is also widely cultivated in China, with a harvested area of 0.65 million hectares $(51.1 \%$ of the world total) in 2018 (FAOSTAT, 2019). In addition, $\mathrm{Cu}$ is an essential element for plant functioning in normal conditions, using active and passive transport systems during uptake, whereas $\mathrm{Pb}$ is a highly toxic element without any known essential function in plants, using passive transport systems (e.g., the apoplastic pathway or via $\mathrm{Ca}^{2+}$-permeable channels) during uptake (Trakal et al., 2013, 2015). Therefore, $\mathrm{Pb}$ and $\mathrm{Cu}$ are likely to present some specificity in 
their induced hormetic effect and their toxicity mechanism in lettuce. Revealing the toxicity and transport mechanism of $\mathrm{Pb}$ (a representative toxic element) and $\mathrm{Cu}$ (a representative essential element) in lettuce using advanced techniques can show us a clearer knowledge on the health risks of different kind of PTEs via visually healthy lettuces intake. In the current study, differential centrifugation, ICP-MS, and $\mu$-XRF were utilized to investigate the toxicity and transport of $\mathrm{Pb}$ and $\mathrm{Cu}$ in lettuce under elevated $\mathrm{Pb}$ and $\mathrm{Cu}$ levels in the soil-plant system.

We hypothesized that $\mathrm{Pb}$ and $\mathrm{Cu}$ induced hormetic effect and toxicity mechanisms in lettuce are different due to the different elemental characteristics of $\mathrm{Pb}$ and $\mathrm{Cu}$. This may result in different tolerance limits of $\mathrm{Pb}$ and $\mathrm{Cu}$ for food safety, the level that initiates a decrease in lettuce weight, and the level that indicates no seed development. The objectives of this study were to: (1) reveal $\mathrm{Pb}$ and $\mathrm{Cu}$ induced hormetic effect and toxicity to lettuce; (2) investigate the subcellular distribution of $\mathrm{Pb}$ and $\mathrm{Cu}$ in lettuce and its toxicity mechanism; and (3) explore the visual distribution of $\mathrm{Pb}$ and $\mathrm{Cu}$ in lettuce seeds and tissues as well as the toxicity and transport mechanism of $\mathrm{Pb}$ and $\mathrm{Cu}$.

\section{Materials and methods}

\subsection{Pot experiment}

The pristine or PTEs-uncontaminated loam soil (at depths of 0-20 cm) was collected from Dareng Village $\left(19.08^{\circ} \mathrm{N}, 109.06^{\circ} \mathrm{E}\right)$ in Changjiang County, Hainan Province, China. The soil was classified as Udic Ferralsol in accordance with the soil classification system of the Food and Agricultural Organization of the United Nations (with a soil texture of loam). The collected soil was amended with $2.3 \%(\mathrm{w} / \mathrm{w})$ corn straw biochar and incubated for 3 months. The $\mathrm{pH}$ value of the resulting soil was 6.3 , and its soil organic carbon and cation exchange capacity were $29.7 \mathrm{~g} \mathrm{~kg}^{-1}$ and $94.2 \mathrm{mmol} \mathrm{kg}$, respectively. The concentrations of total nitrogen, total phosphorus, and available potassium of the soil were $1.32,0.46$, and $0.41 \mathrm{~g} \mathrm{~kg}^{-1}$, respectively. The total $\mathrm{Pb}$ and $\mathrm{Cu}$ concentrations 
of the soil were $55.3 \mathrm{mg} \mathrm{kg}^{-1}$ and $9.51 \mathrm{mg} \mathrm{kg}^{-1}$, respectively.

The soil was air-dried, sieved $(<2 \mathrm{~mm})$, and then stored in air-tight plastic bags prior to the pot experiment. To prepare the contaminated soil for the pot experiment, $2 \mathrm{~kg}$ of each mixed soil (dry weight) was placed into a plastic cask, and deionized water was then added to reach the $50 \%$ water holding capacity of the soil. The aim was to allow the $\mathrm{Pb}\left(\mathrm{NO}_{3}\right)_{2}$ or $\mathrm{Cu}\left(\mathrm{NO}_{3}\right)_{2}$ aqueous solutions to uniformly disperse into the soil. To achieve an elevated $\mathrm{Pb}$ and $\mathrm{Cu}$ stress in the studied soils, seven treatments with final $\mathrm{Pb}$ or $\mathrm{Cu}$ contents of 0, 25, 50, 250, 500, 2500, or $5000 \mathrm{mg} \mathrm{kg}^{-1}$ were prepared separately. Specifically, the soil samples were spiked with $200 \mathrm{~mL}$ of 0 , 1.206, 2.41, 12.06, 24.13, 120.6, or $241.3 \mathrm{mM} \mathrm{Pb}\left(\mathrm{NO}_{3}\right)_{2}$ aqueous solution as well as $0,3.93,7.87,39.3,78.7$, 393.4 , or $786.8 \mathrm{mM} \mathrm{Cu}\left(\mathrm{NO}_{3}\right)_{2}$ aqueous solution, respectively. Accordingly, the risk screening values of $\mathrm{Pb}$ and $\mathrm{Cu}$ for the new soil environmental quality standard of agricultural land in China (designated GB 15618-2018) under a soil $\mathrm{pH}$ of 5.5-6.5 were $100 \mathrm{mg} \mathrm{kg}^{-1}$ and $50 \mathrm{mg} \mathrm{kg}^{-1}$, respectively. Contaminated soils were aged for 3 months and their moisture contents in casks were adjusted daily to maintain a constant $70 \%$ of the water holding capacity.

After incubation of the $\mathrm{Pb}$ and $\mathrm{Cu}$ contaminated soil, the soil samples were air-dried and weighed in a polyethylene pot $\left(500 \mathrm{~g} \mathrm{pot}^{-1}\right)$ for the experiment. A detailed description of lettuce growth experiment is given in the Supporting Information (Text S1). The plants were harvested for analysis after 40 days of growth, when they had reached the mature stage and were ready to be consumed.

\subsection{Separation and analysis of subcellular fractions}

Fresh lettuce plants were washed with deionized water and divided into shoots and roots. Next, $4.0 \mathrm{~g}$ of lettuce shoots and $3.0 \mathrm{~g}$ of lettuce roots from each treatment were weighed and homogenized in a medium with $20 \mathrm{~mL}$ of $250 \mathrm{mM}$ sucrose, $1.0 \mathrm{mM}$ dithioerythritol, and $50 \mathrm{mM}$ Tris- $\mathrm{HCl}$ (at $\mathrm{pH} 7.5$ ). The medium had been cooled to $4^{\circ} \mathrm{C}$ prior to the addition of homogenate. The homogenate was then filtered through a nylon cloth $(80 \mu \mathrm{m})$, and the 
residue was washed with $5 \mathrm{~mL}$ of the medium. The material collected on the nylon cloth (Wu et al., 2013) was adopted as the cell wall subcellular fraction (SV). Finally, the supernatant was separated according to Wu et al. (2013) into the plastid (SIV), nucleus (SIII), and mitochondrion (SII) fractions at $4^{\circ} \mathrm{C}$ using a refrigerated centrifuge (H2050R, Cence, China). The last supernatant was designated the soluble fraction (SI). All of the subcellular fractions of lettuce roots and shoots were freeze-dried and digested with a concentrated mixture of $\mathrm{HNO}_{3}$ and $\mathrm{H}_{2} \mathrm{O}_{2}(3 \mathrm{~mL} ; 2: 1 \mathrm{v} / \mathrm{v})$ in a microwave digestion system (MDS-6, SINED, China). Lead and Cu concentrations were determined using inductively coupled plasma-mass spectrometry (X 7, Thermo Fisher, USA).

\subsection{Analysis of plant and soil samples}

Before harvesting the lettuce, chlorophyll content was measured using a chlorophyll analyzer (SPAD-502 Plus, Konica Minolta, Japan). The chlorophyll content of the lettuce leaves on the 40th day of growth was measured 5 times for each pot. After harvesting, several lettuce plants were randomly selected from each pot and divided into shoots and roots. The shoots and roots were dried in an oven at $105^{\circ} \mathrm{C}$ for 30 minutes and $70^{\circ} \mathrm{C}$ for 48 hours. The dried plant samples were ground and sieved $(<0.5 \mathrm{~mm})$, and $0.3 \mathrm{~g}$ of each sample was weighed in a polytetrafluoroethylene digestion tube. The samples were then digested with a concentrated solution of $\mathrm{HNO}_{3}$ and $\mathrm{H}_{2} \mathrm{O}_{2}(6 \mathrm{~mL} ; 2: 1 \mathrm{v} / \mathrm{v})$ in a microwave digestion system.

In order to estimate the availability of the PTEs in the soil, $0.05 \mathrm{M}$ ethylenediaminetetraacetic acid (EDTA) was used (Liu et al., 2017). Soil pH was measured with a pH meter, using a mixture of soil and deionized aqueous solution (w/v ratio, 1:2.5) that was shaken for $30 \mathrm{~min}$. The $1 \mathrm{M}$ ammonium acetate $(\mathrm{pH} 7.0)$ method was used to determine the cation exchange capacity as well as the levels of several exchangeable mineral elements (i.e., K, $\mathrm{Ca}, \mathrm{Mg}$, and $\mathrm{Zn}$ ) in the soil (Rayment and Higginson, 1992). The $\mathrm{K}_{2} \mathrm{Cr}_{2} \mathrm{O}_{7}$-heating method based on Bao (2000) was chosen to measure the content of soil organic carbon. Total phosphorus $\left(\mathrm{P}_{\mathrm{tot}}\right), \mathrm{Pb}$, and $\mathrm{Cu}$ concentrations in the soil were determined according to an improved method based on Webb and Adeloju (2013) and Wu et al. 
(2014). These concentrations were measured by digesting $0.1 \mathrm{~g}$ of soil samples $(0.149 \mathrm{~mm}$ sieved) with $6 \mathrm{~mL}$ of solution $\left(\mathrm{HNO}_{3} / \mathrm{H}_{2} \mathrm{O}_{2} / \mathrm{HF} ; 3 / 2 / 1 \mathrm{v} / \mathrm{v} / \mathrm{v}\right)$ in a microwave digestion system (MDS-6, SINED, China). The temperature was maintained at $85^{\circ} \mathrm{C}$ for $3 \mathrm{~min}, 125^{\circ} \mathrm{C}$ for $6 \mathrm{~min}$, and $150^{\circ} \mathrm{C}$ for $6 \mathrm{~min}$. The soil total nitrogen $\left(\mathrm{N}_{\mathrm{tot}}\right)$ was determined using a multi N/C analyzer (multi N/C 2100, Analytik Jena AG, Germany).

Concentrations of $\mathrm{Pb}, \mathrm{Cu}$, and $\mathrm{P}$ in the digested solutions were measured using an ICP-MS. The translocation factor (TF) was used to evaluate the ability of plants to translocate $\mathrm{Pb}$ or $\mathrm{Cu}$ from the roots to the shoots using the following equation:

$$
\mathrm{TF}=100 \% \times \mathrm{C}_{\text {shoot }} / \mathrm{C}_{\text {root }}
$$

where $\mathrm{C}$ refers to the concentration of PTE in tissues $\left(\mathrm{mg} \mathrm{kg}^{-1} \mathrm{DW}\right)$, and shoot refers to stems and leaves (Wu et al., 2013).

\subsection{Micro-X-ray fluorescence $(\mu-X R F)$ analysis}

Thin longitudinal sections $(50 \mu \mathrm{m})$ of lettuce seeds and seedlings were prepared on the 5 th day after sowing and placed on Kapton tape for $\mu$-XRF analysis. This was accomplished using the beamline 4W1B of the Beijing Synchrotron Radiation Facility (BSRF, China), which runs $2.5 \mathrm{GeV}$ electron with a current ranging from 150 to $250 \mathrm{~mA}$. A detailed description of sample collection and preparation is found in the Supporting Information (Text S2). The data reduction and processing were performed using PyMca software (Solé et al., 2007).

\subsection{Statistical analysis}

Results were expressed on a dry weight basis (mean \pm standard deviation of 3 replicates per treatment). The plant weight, chlorophyll of leaves, and concentrations of $\mathrm{Pb}$ and $\mathrm{Cu}$ in the tissues and subcellular fractions of lettuce under different treatments were analyzed via ANOVA (with a 95.0\% confidence level) according to Tukey's multiple-range tests $(p<0.05)$. Statistical analysis was carried out using SAS 9.1 software (SAS Institute, Inc., USA), and the figures were designed using Origin 8.0 software (Origin Lab, USA). 


\section{Results}

\subsection{Growth of lettuce and its PTEs content under elevated $\mathrm{Pb}$ and $\mathrm{Cu}$ stress}

The photos and detailed descriptions of lettuce growth status during the seedling period (the 5th day after sowing) and the harvest period (the 40th day) under $\mathrm{Pb}$ and $\mathrm{Cu}$ stress are shown in Fig. S1 and Text S3 of the Supporting Information, respectively. There was a significant $(p<0.05)$ increase in the fresh weight of lettuce plants (yield) and the chlorophyll of leaves (SPAD value) at $\mathrm{Cu}$ concentrations of $250 \mathrm{mg} \mathrm{kg}^{-1}$ when compared to the control treatment, while only significant increase in SPAD value at the same Pb level (Fig. 1). Lettuce fresh weight significantly decreased from 28.3 to $2.62 \mathrm{~g} \mathrm{pot}^{-1}$ and the chlorophyll of leaves decreased from 26.7 to 18.0 with the increase in $\mathrm{Cu}$ level from 250 to $500 \mathrm{mg} \mathrm{kg}^{-1}$. The chlorophyll of leaves (SPAD) was significantly reduced from 25.9 to 22.9 and lettuce fresh weight was significantly reduced from 24.3 to $2.83 \mathrm{~g} \mathrm{pot}^{-1}$ with the increase in $\mathrm{Pb}$ level from 500 to $2500 \mathrm{mg} \mathrm{kg}^{-1}$ (Fig. 1; Table S1). Therefore, a dose response phenomenon characterized by low-dose stimulation and high-dose inhibition was observed in the lettuce pot experiment under $\mathrm{Pb}$ and $\mathrm{Cu}$ stress, as shown in the "I," "II," “III," and "IV” regions of Fig. 1.

The $\mathrm{Pb}$ toxicity in lettuce appeared at higher concentrations (i.e., $2500 \mathrm{mg} \mathrm{kg}^{-1}$ ) than $\mathrm{Cu}$ toxicity (i.e., $500 \mathrm{mg}$ $\mathrm{kg}^{-1}$ ) as $\mathrm{Pb}$ and $\mathrm{Cu}$ levels were increased in the soil (Fig. 1; Figs. S1C, D). The response curve of lettuce fresh weight to the total PTE content in the studied soil under elevated $\mathrm{Pb}$ and $\mathrm{Cu}$ stress can be well expressed via a quadratic polynomial model, as shown in Figs. 2a, b. The fitted models were demonstrated by plotting the measured weight of lettuce plants under $\mathrm{Pb}$ and $\mathrm{Cu}$ stress against the corresponding calculated values (Figs. S2A, $\mathrm{B})$. The results revealed that the lettuce yield began to decrease when $\mathrm{Pb}$ and $\mathrm{Cu}$ contents in the studied soil reached $997.2 \mathrm{mg} \mathrm{kg}^{-1}$ and $212.1 \mathrm{mg} \mathrm{kg}^{-1}$, respectively (points $\mathrm{A}$ and $\mathrm{C}$ in Figs. 2a, b). Moreover, $\mathrm{Pb}$ and $\mathrm{Cu}$ contents in the soil were $2643.5 \mathrm{mg} \mathrm{kg}^{-1}$ and $525.4 \mathrm{mg} \mathrm{kg}^{-1}$, respectively, when the lettuce yield decreased to $0 \mathrm{~g}$ pot $^{-1}$ (points B and D in Figs. 2a, b). 

$\mathrm{mg} \mathrm{kg}^{-1}$ (GB 2762-2017) and $10 \mathrm{mg} \mathrm{kg}^{-1}$ (GB 15199-94), respectively. Concentrations of $\mathrm{Pb}$ and $\mathrm{Cu}$ in fresh lettuce shoots at the $\mathrm{Pb}$ level of $25 \mathrm{mg} \mathrm{kg}^{-1}$ and the $\mathrm{Cu}$ level of $50 \mathrm{mg} \mathrm{kg}^{-1}$ were 0.28 and $8.54 \mathrm{mg} \mathrm{kg}^{-1}$, respectively and (2):

$$
\mathrm{y}=\mathrm{a}+\mathrm{bx}
$$

$$
\mathrm{y}=\mathrm{e}-\mathrm{c} \cdot \mathrm{d}^{\mathrm{x}}
$$

where $\mathrm{a}, \mathrm{b}, \mathrm{c}, \mathrm{d}$ and e are constants of the fitting equations.

The fitted models were found to be reliable (Figs. S2C, D). To reach the tolerance limits of $\mathrm{Pb}$ and $\mathrm{Cu}$ for leafy vegetables in China, we calculated that the total $\mathrm{Pb}$ and $\mathrm{Cu}$ concentrations of the studied soil would need to be 65.1 and $89.9 \mathrm{mg} \mathrm{kg}^{-1}$, respectively (points E and F in Figs. 2c, d).

\subsection{Availability of $\mathrm{Pb}, \mathrm{Cu}$, and other mineral elements in the soil}

The EDTA-extractable $\mathrm{Pb}$ and $\mathrm{Cu}$ content in the studied soil before lettuce sowing increased with increasing

$\mathrm{Pb}$ and $\mathrm{Cu}$ contamination levels (Table S3). A quadratic polynomial equation could well describe EDTAsignificantly lower than $\mathrm{Cu}$ ion content (Table S3). The EDTA-extractable $\mathrm{Pb}$ ion content $\left(0.06 \mathrm{mmol} \mathrm{kg}^{-1}\right.$ under a soil $\mathrm{Pb}$ concentration of $\left.65.1 \mathrm{mg} \mathrm{kg}^{-1}\right)$ was lower than $\mathrm{Cu}(0.53 \mathrm{mmol} \mathrm{kg}-1$ under a soil $\mathrm{Cu}$ concentration of 89.9 $\mathrm{mg} \mathrm{kg}^{-1}$ ) at the food safety threshold value (points E and G in Fig. S3). However, the EDTA-extractable Pb ion content (3.53 mmol kg-1 under a $\mathrm{Pb}$ concentration of $\left.997 \mathrm{mg} \mathrm{kg}^{-1}\right)$ was higher than $\mathrm{Cu}\left(1.37 \mathrm{mmol} \mathrm{kg}^{-1}\right.$ under a 
exchangeable $\mathrm{K}, \mathrm{Ca}, \mathrm{Mg}$, and $\mathrm{Zn}$ in the studied soil increased with increasing $\mathrm{Pb}$ and $\mathrm{Cu}$ contamination levels, while the $\mathrm{pH}$ values significantly decreased with increasing PTEs levels (Table S4).

\subsection{Distribution of $\mathrm{Pb}$ and $\mathrm{Cu}$ in plant tissue}

Lead and $\mathrm{Cu}$ concentrations in each shoot and root tissue increased significantly $(p<0.05)$ with increasing $\mathrm{Pb}$ and $\mathrm{Cu}$ levels in the soil (Table 1 and Fig. S4), with the exception of those at the Pb level of $25 \mathrm{mg} \mathrm{kg}^{-1}(p>0.05)$. Before the lettuce was seriously poisoned, the maximum $\mathrm{Pb}$ and $\mathrm{Cu}$ concentrations in the shoots were 433 and $300 \mathrm{mg} \mathrm{kg}^{-1}$ dry weight (DW), respectively, while the maximum $\mathrm{Pb}$ and $\mathrm{Cu}$ concentrations in the roots were 1789 and $2353 \mathrm{mg} \mathrm{kg}^{-1} \mathrm{DW}$, respectively (Table 1). Copper concentrations in the lettuce tissues were higher than $\mathrm{Pb}$ concentrations at the same contamination levels. The $\mathrm{Pb}$ translocation factors $(33.1 \%-23.6 \%)$ from the roots to the shoots slowly decreased with increasing $\mathrm{Pb}$ levels (Fig. S5). The $\mathrm{Cu}$ translocation factors $(65.5 \%-12.7 \%)$, however, sharply decreased with increasing Cu levels (Fig. S5).

\subsection{Subcellular distribution of $\mathrm{Pb}$ and $\mathrm{Cu}$ in plants}

The $\mathrm{Pb}$ and $\mathrm{Cu}$ concentrations in the different subcellular fractions of lettuce increased with increasing $\mathrm{Pb}$ and $\mathrm{Cu}$ levels in the soil (Table S2). As the $\mathrm{Pb}$ level increased from 0 to $500 \mathrm{mg} \mathrm{kg}^{-1}$, the $\mathrm{Pb}$ concentrations in the supernatant soluble fraction, mitochondrion, nucleus, plastid, and cell wall fractions of the lettuce respectively increased by 132-, 63.3-, 37.8-, 85.6-, and 47.4-fold in shoots and 170-, 30.3-, 31.3-, 64.5-, and 103-fold in roots compared to the control. When exposed to $250 \mathrm{mg} \mathrm{kg}^{-1}$ of $\mathrm{Cu}$, the $\mathrm{Cu}$ concentration in the soluble fraction, mitochondrion, nucleus, plastid, and cell wall fractions of the lettuce respectively increased by 3.1-, 5-, 10-, 3.4-, and 3.9-fold in shoots and 27.8-, 9.9-, 9.6-, 9.2-, and 23.6-fold in roots compared to the control.

Moreover, the percentage of $\mathrm{Pb}$ in the soluble fraction increased from 29.4 to $50.7 \%$ in the shoots. As the $\mathrm{Pb}$ level increased from 0 to $500 \mathrm{mg} \mathrm{kg}^{-1}$, the percentages of $\mathrm{Pb}$ in the mitochondrion, nucleus, and cell wall fractions decreased from $17.6 \%$ to $14.6 \%, 23.5 \%$ to $11.6 \%$, and $20 \%$ to $12.4 \%$, respectively (Fig. $3 \mathrm{~A}$ ). In the roots, as the 
$67 \mathrm{~Pb}$ level increased from 0 to $500 \mathrm{mg} \mathrm{kg}^{-1}$, the percentages of $\mathrm{Pb}$ in the soluble fraction and cell wall fraction increased from $22.5 \%$ to $37.9 \%$ and $23 \%$ to $41 \%$, respectively (Fig. 3B). In contrast, the percentages of $\mathrm{Pb}$ in the mitochondrion, nucleus, and plastid fractions in the roots were significantly reduced.

As the $\mathrm{Cu}$ level increased from 0 to $250 \mathrm{mg} \mathrm{kg}^{-1}$, the percentage of $\mathrm{Cu}$ in the soluble fraction of shoots (Fig.

3C) decreased from $51.4 \%$ to $42 \%$, while the percentages of $\mathrm{Cu}$ in the mitochondrion and nucleus fractions increased slightly from $8.3 \%$ to $11 \%$ and $3.9 \%$ to $10.7 \%$, respectively. When the $\mathrm{Cu}$ level increased from 0 to 250 $\mathrm{mg} \mathrm{kg}^{-1}$, the percentages of $\mathrm{Cu}$ in the soluble fraction and cell wall fraction of plant roots increased from $32.4 \%$ to $46.1 \%$ and $29 \%$ to $35.1 \%$, respectively (Fig. 3D). The percentages of $\mathrm{Cu}$ in the nucleus, plastid, and mitochondrion fractions were slightly decreased, however.

\subsection{Distribution of $\mathrm{Pb}, \mathrm{Cu}$, and other elements in longitudinal sections of lettuce seeds and seedlings}

The distribution patterns of different elements in the longitudinal sections, as well as photos of seeds and seedlings under different $\mathrm{Pb}$ and $\mathrm{Cu}$ levels, are shown in Figs. 4-7. The $\mathrm{Pb}$ intensities over the entire longitudinal section of lettuce seeds under severe $\mathrm{Pb}$ levels (5000 $\mathrm{mg} \mathrm{kg}^{-1}$; Fig. 4B) indicate that $\mathrm{Pb}$ was mainly distributed on the hypocotyl side (including the hypocotyl, shoot apex, and root apex) of seeds (region "a" in Fig. 4). In the cotyledon side region (including the cotyledons, endosperm, and seed coat) of seeds (region "b" in Fig. 4), Pb exhibited a more constrained distribution (Fig. 4B). Higher intensities of Mn, Fe, and Zn (Figs. 4E, F, H) were detected on the hypocotyl side (region "a"). However, K and Ca (Figs. 4C, D) exhibited higher intensities on both the hypocotyl side and cotyledon side of lettuce seeds. According to the Pearson correlation coefficient (Table S5), $\mathrm{Pb}$ was significantly correlated with other elements $(\mathrm{R}=0.839 * *$ for $\mathrm{Fe}, 0.624 * *$ for $\mathrm{Ca}$, and $0.603 * *$ for $\mathrm{Mn})$ in lettuce seeds. The high $\mathrm{Cu}$ concentrations were distributed over almost the entire seed under severe $\mathrm{Cu}$ levels (2500 $\mathrm{mg} \mathrm{kg}^{-1}$ ), although higher $\mathrm{Cu}$ concentrations were found on both the hypocotyl side (region "c" in Fig. 5B) 
(Figs. 5C-G) were observed on the tops of the hypocotyl and cotyledon sides of lettuce seeds. Copper was

significantly correlated with other elements $(\mathrm{R}=0.874 * *$ for $\mathrm{Mn}, 0.663 * *$ for $\mathrm{Fe}$, and $0.337 * *$ for $\mathrm{Ca})$ in lettuce seeds (Table S5).

High concentrations of $\mathrm{K}, \mathrm{Ca}, \mathrm{Mn}, \mathrm{Fe}, \mathrm{Cu}$, and $\mathrm{Zn}$ (Figs. 6C-H) and low concentrations of $\mathrm{Pb}($ Fig. 6B) accumulated in both the upper half (i.e., shoots) and lower half (i.e., roots) of lettuce seedlings (Fig. 6A) under Pb stress $\left(50 \mathrm{mg} \mathrm{kg}^{-1}\right)$. In the longitudinal section of shoots (Fig. 7a) of lettuce seedling under Cu stress $\left(50 \mathrm{mg} \mathrm{kg}^{-1}\right)$, high $\mathrm{K}, \mathrm{Ca}, \mathrm{Cu}, \mathrm{Mn}, \mathrm{Fe}$, and Zn (Figs. 7a B-G) contents were found in the stem area (region "e" in Fig. 7a) and at the leaf edge. Weak intensities of $\mathrm{Pb}($ Fig. $7 \mathrm{a} \mathrm{H})$ were detected in the shoots of lettuce seedling under $\mathrm{Cu}$ stress. In lettuce seedling roots (Fig. 7b) under $\mathrm{Cu}$ stress $\left(50 \mathrm{mg} \mathrm{kg}^{-1}\right.$ ), high intensities of $\mathrm{K}, \mathrm{Ca}$, and $\mathrm{Zn}$ (Figs. 7b C, D, G) were found in both the root hair zone (region "f" in Fig. 7b) and the stem area, while high intensities of $\mathrm{Cu}$, Mn, and Fe (Figs. 7b B, E, F) were mainly detected in the root hair zone. Weak intensities of Pb (Fig. 7b H) were also observed in the young root hair zone and the young stems of lettuce seedlings under $\mathrm{Cu}$ stress. The distribution between $\mathrm{Cu}$ and $\mathrm{Fe}\left(\mathrm{R}=0.766^{* *}\right.$ for $\left.\mathrm{Fe}\right)$ was significantly related (Table S5).

\section{Discussion}

\subsection{Lead and copper-induced hormetic effect and toxicity to lettuce}

The increased lettuce yield and leaf chlorophyll in response to low concentrations of PTEs (i.e., $\mathrm{Pb}$ and $\mathrm{Cu}$ ) in regions "I," "II," "III," and "IV" (Fig. 1) and the inhibition at high concentrations, indicate a hormetic effect (Shahid et al., 2017). The hormetic effect, a dose-response phenomenon characterized by low-dose stimulation and high-dose inhibition (Shahid et al., 2019), is commonly found in toxicological evaluations of biomedical applications (Calabrese, 2008; Shahid et al., 2019). A marked hormetic effect was found in a cultivation experiment of Jatropha curcas L. cuttings under soil Pb-stress (Shu et al., 2012). Shu et al. (2012) discovered that the leaf area as well as the chlorophyll a and b contents in cuttings all peaked at Pb levels of $100 \mathrm{mg} \mathrm{kg}^{-1}$. Similarly, 
the root biomass of carrot attains the highest value at a Cu level of $200 \mathrm{mg} \mathrm{kg}^{-1}$ (Hou et al., 2018).

The lettuce, grow in the studied soil at $\mathrm{Pb}$ or $\mathrm{Cu}$ level of $250 \mathrm{mg} \mathrm{kg}^{-1}$, might be regarded as visually healthy vegetable by people since the lettuce yield and leaf chlorophyll of these lettuce plants was higher than that of lettuce in the control treatment. The content of $\mathrm{Pb}\left(6.33 \mathrm{mg} \mathrm{kg}^{-1}\right)$ and $\mathrm{Cu}\left(12.1 \mathrm{mg} \mathrm{kg}^{-1}\right)$ in lettuce shoots, however, was 21.1- and 1.2-fold the tolerance limit for $\mathrm{Pb}\left(0.30 \mathrm{mg} \mathrm{kg}^{-1}\right)$ and $\mathrm{Cu}\left(10 \mathrm{mg} \mathrm{kg}^{-1}\right)$ in fresh leafy vegetables in China, where the significantly higher limit for $\mathrm{Cu}$ is caused due to its nutrient essentiality. Yuan et al. (2019) reported that long-term consumption of polluted vegetables (with PTEs exceeded the contamination limitations for food in China) grown in PTE-contaminated soils, especially cabbage and lettuce, are likely to increase carcinogenic and non-carcinogenic health risks. Thus, the health risk of $\mathrm{Pb}$ in the visually healthy lettuce was much higher than that of $\mathrm{Cu}$ under the same soil contamination level.

In addition, our results revealed that the increase in yield and leaf chlorophyll of lettuce occurred over a larger range of $\mathrm{Pb}$ concentrations than $\mathrm{Cu}$ concentrations (Fig. 1). This may be primarily attributed to the higher extractable ion content of $\mathrm{Cu}$ than $\mathrm{Pb}$ in contaminated soil under the same severe PTE level. Thus, more damaging $\mathrm{Cu}$ ions would be taken up by lettuce plants than $\mathrm{Pb}$ ions. The excessively absorbed $\mathrm{Cu}$ and $\mathrm{Pb}$ ions may also interfere with various structural, physiological, and biochemical aspects of lettuce processes, thereby inhibiting the growth of the plant and sometimes resulting in plant death (Setia et al., 2018). Moreover, the toxicity of $\mathrm{Pb}$ and $\mathrm{Cu}$ also significantly affects the chlorophyll content in lettuce under severe PTE levels (Fig. 1), which inhibits plant growth (Ali et al., 2015). The mineral nutrients, e.g., K, Ca, Mg, and Zn, in soil that are exchanged and released by $\mathrm{Pb}^{2+}$ and $\mathrm{Cu}^{2+}$ (Table $\mathrm{S} 4$ ) under $\mathrm{Pb}$ (less than $2500 \mathrm{mg} \mathrm{kg}^{-1}$ ) and $\mathrm{Cu}$ level (less than $500 \mathrm{mg} \mathrm{kg}^{-1}$ ) may contribute to the hormetic effect of biomass and chlorophyll (SPAD) in lettuce.

The PTEs concentrations in lettuce plants reach 3 levels after the PTEs absorption: the tolerance limit of PTEs for food safety, the level that initiates a decrease in lettuce weight, and the level that results in lettuce seed mortality. 
Based on the fitted models (Figs. 2, S2 and Text S4), we suggest that the total $\mathrm{Pb}$ and $\mathrm{Cu}$ concentrations in the studied soil are 65.1 and $89.9 \mathrm{mg} \mathrm{kg}^{-1}, 997.2$ and $212.1 \mathrm{mg} \mathrm{kg}^{-1}$, and 2643.5 and $525.4 \mathrm{mg} \mathrm{kg}^{-1}$ for the 3 PTEloaded capacities of soil for growing lettuce, respectively, i.e., the PTE-loaded capacity that ensures food safety (PCEFS), the PTE-loaded capacity that limits yield (PCLY), and the PTE-loaded capacity that kills seeds (PCKS).

The $\mathrm{Pb}$ concentration for the PCEFS in the studied soil was lower than $100 \mathrm{mg} \mathrm{kg}^{-1}$, which is the risk screening value for soil contamination of agricultural land at pH levels of 5.5-6.5 in China (GB 15618-2018). However, the $\mathrm{Cu}$ concentration for the PCEFS in the studied soil was higher than $50 \mathrm{mg} \mathrm{kg}^{-1}$, which is the risk screening value of $\mathrm{Cu}$ in China (GB 15618-2018). The Pb concentrations for the PCLY and PCKS in soil were nearly 2and 5-fold the $500 \mathrm{mg} \mathrm{kg}^{-1}$ risk intervention value for soil contamination of agricultural land at $\mathrm{pH}$ levels of 5.5-6.5 in China, respectively (GB 15618-2018). There is no risk intervention value of Cu in China. Nevertheless, the $\mathrm{Cu}$ concentrations for the PCLY and PCKS in the studied soil were approximately 4- and 10-fold the risk screening value of $\mathrm{Cu}$ in China (50 $\mathrm{mg} \mathrm{kg}^{-1}$ ), respectively (GB 15618-2018).

The food safety threshold and environmental lethal threshold of PTEs have been studied by several researchers (Ferri et al., 2015; Ding et al., 2015; Gomes et al., 2013). It assumes that when a certain study soil is chosen, the soil will have a specific capacity to load a PTE, since the elemental physicochemical properties of the soil are specific. Therefore, the PCEFS, PCLY, and PCKS values of a PTE for a particular crop in the study soil are also definite. This means that these PTEs capacities for a crop can be used to indirectly assess the contamination degree of the cultivated soil.

The PCLY and PCKS values of $\mathrm{Cu}$ in the studied soil were far lower than those of $\mathrm{Pb}$. This might be related to concentration of bioavailable $\mathrm{Pb}$ and $\mathrm{Cu}$ in the soil, the toxicity of $\mathrm{Pb}$ and $\mathrm{Cu}$ to lettuce as well as the capacity of the plant for $\mathrm{Pb}$ and $\mathrm{Cu}$ uptake. Copper is an essential element for plants; in contrast, $\mathrm{Pb}$ is an unnecessary element (Gruszecka-Kosowska, 2019). Consequently, $\mathrm{Cu}$ is largely taken up and transported by plants, while $\mathrm{Pb}$ 
155

156

157

158

159

160

161

162

163

164

165

is mainly excluded by plants or accumulates in their roots (Table 1). Generally, a particular crop displays different tolerances to different kinds of PTEs (Hou et al., 2018).

Soil properties, such as $\mathrm{pH}$, cation exchange capacity, and organic matter, exert significant impacts on the content of available PTEs, i.e., the primary fraction of the PTEs uptake of plants from contaminated soils that affects the PTEs thresholds of plants in different soils (Ding et al., 2015; Wenzel, 2009). Our results indicated that the tolerance of lettuce to $\mathrm{Pb}$ and $\mathrm{Cu}$ was mainly affected by EDTA-extractable $\mathrm{Pb}$ and $\mathrm{Cu}$ ion content in the studied soil (Table S3 and Fig. S3). Soil pH values were significantly correlated with extractable PTEs contents in contaminated soil (Lu et al., 2017a). The higher the PTEs level in the contaminated soil, the lower the soil pH value (Table $\mathrm{S} 4$ ), which may contribute to the higher EDTA-extractable $\mathrm{Pb}$ and $\mathrm{Cu}$ in the soils under severe PTEs levels (Table S3). Moreover, available $\mathrm{Pb}$ exhibited a good correlation with $\mathrm{Pb}$ content in plants in contaminated soils (Ding et al., 2015). The lettuce plants could take up more extractable $\mathrm{Pb}$ and $\mathrm{Cu}$ ions in the contaminated soils under severe PTE levels until serious root damage occurred.

\subsection{Distribution and translocation factor of $\mathrm{Pb}$ and $\mathrm{Cu}$ in plant tissues}

The translocation factor (TF) of $\mathrm{Cu}$ in lettuce decreased significantly (from 65\% to $13 \%$ ) with increasing $\mathrm{Cu}$ levels, whereas the TF of $\mathrm{Pb}$ was maintained at a low level (23\%-33\%) under different $\mathrm{Pb}$ levels (Table 1). This might be related to the different absorption and transport mechanisms of $\mathrm{Pb}$ and $\mathrm{Cu}$ in lettuce. To our knowledge, soil water with dissolved PTEs can enter up to the parenchyma via the apoplast or enter into the cells via the symplast during the PTEs uptake of plant roots (Trakal et al., 2015). Once in the endodermis, the Casparian strip forces all of the water and PTEs to follow the intracellular pathway (across the plasma membrane) using the active or passive transport systems (Trakal et al., 2015).

Copper uptake in root cells is passed through the symplast via active and passive transport, while $\mathrm{Pb}$ uptake is passed by the apoplastic pathway or via $\mathrm{Ca}^{2+}$-permeable channels (i.e., passive transport; Trakal et al., 2015). 
177 The cell membranes of plants contain proteins known as "proton pumps" that regulate the flow of $\mathrm{Cu}$ ions into

178

179 cells (Himelblau and Amasino, 2000). After Cu-uptake into the cell, copper chaperones (involved in intracellular transport) sequester $\mathrm{Cu}$ in a non-reactive form and interact with other transport proteins to transport $\mathrm{Cu}$ to the sites where plant metabolism is needed (Himelblau and Amasino, 2000). Therefore, $\mathrm{Cu}$ could easily be transported into lettuce shoots under a suitable $\mathrm{Cu}$ level.

Kabata-Pendias (2011), however, reported that all of the elements are taken up passively when their concentrations exceed a threshold value, a situation that occurs in contaminated soils with high concentrations of PTEs. This means that under severe $\mathrm{Cu}$ levels, $\mathrm{Cu}$ would be forced to pass through a passive transport pathway into cells, making it more difficult to transport $\mathrm{Cu}$ into shoots (Trakal et al., 2013). Lead ions only move via passive transport systems (Trakal et al., 2013), exhibiting a low translocation factor in lettuce. Overall, accumulating PTEs (i.e., $\mathrm{Pb}$ and $\mathrm{Cu}$ ) in the root tissues is a primary tolerance strategy in King 118 lettuce (Lactuca sativa L.) in response to elevated levels of PTEs. Moreover, the resistance to transfer in lettuce was higher for $\mathrm{Cu}$ than it was for $\mathrm{Pb}$.

\subsection{Subcellular distribution of $\mathrm{Pb}$ and $\mathrm{Cu}$ in lettuce}

Although the absolute concentrations of $\mathrm{Pb}$ and $\mathrm{Cu}$ in each subcellular structure of lettuce roots increased significantly with increasing $\mathrm{Pb}$ and $\mathrm{Cu}$ levels, the relative contents (percentages) of $\mathrm{Pb}$ and $\mathrm{Cu}$ increased dramatically only in the cell wall and soluble fraction (Table S2). Approximately $80 \%$ of $\mathrm{Pb}$ and $\mathrm{Cu}$ in the roots accumulated in the cell wall and soluble fraction. This was consistent with the subcellular proportions of $\mathrm{Pb}(76 \%)$ in the cell wall and soluble fractions of pak choi roots at a $\mathrm{Pb}$ level of $200 \mathrm{mg} \mathrm{L}^{-1}$ and the proportion of $\mathrm{Cu}(86 \%)$ in the cell wall and soluble fractions of tomato seedling roots at a $\mathrm{Cu}$ level of $3.2 \mathrm{mg} \mathrm{\textrm {L } ^ { - 1 }}$ (Dong et al., 2013; Wu et al., 2013). A possible accumulation mechanism for $\mathrm{Pb}$ and $\mathrm{Cu}$ in roots is chelation via binding sites in the root cell walls (Trakal et al., 2015). Excessive $\mathrm{Pb}$ and $\mathrm{Cu}$ are then sequestered mostly by vacuoles within the cells 
when passing through the plasma membrane in order to protect organelles from their toxicity (Megateli et al., 2009; Wu et al., 2013; Sun and Luo, 2018).

Surprisingly, under elevated PTE stress, Pb exhibited a sharp tendency to be sequestered in the soluble fraction of lettuce shoots; $\mathrm{Cu}$, however, presented a slight tendency to be accumulated in organelles and nuclei (Fig. 3). Consistent with our results, $\mathrm{Cu}$ also tended to be accumulated in the chloroplasts and nuclei of Brassica napus leaves (cultivars Zheda 622) when Cu stress increased from 3.2 to $12.8 \mathrm{mg} \mathrm{L}^{-1}$ (Mwamba et al., 2016). A possible reason for this pattern is that high $\mathrm{Cu}$ stress easily induces significant harm to the architecture of thylakoid membranes in chloroplasts and nucleic acid in the nucleus, after which it accumulates in these cellular structures (Mwamba et al., 2016).

Overall, the subcellular distribution of $\mathrm{Pb}$ in both roots and shoots indicates that lettuce may be actively restricting the accumulation of $\mathrm{Pb}$ in nuclei and organelles as a protective mechanism. This mechanism, however, was shown to exist under $\mathrm{Cu}$ stress in the roots of lettuce, but not in shoots. There may be a delay in the $\mathrm{Cu}$ stress response of shoots when compared to roots. Thus, lettuce can activate its defense systems in time to counter the toxicity of $\mathrm{Pb}$ under severe PTE levels but is delayed in its defense against the toxicity of $\mathrm{Cu}$. This results in higher mortality of lettuce seeds under severe $\mathrm{Cu}$ levels when compared with $\mathrm{Pb}$. This might be the reason that the positive effect on yield and leaf chlorophyll occurs over a wider range of $\mathrm{Pb}$ concentrations than $\mathrm{Cu}$ concentrations (see regions "I-IV" in Fig. 1).

\subsection{Visualized distribution of $\mathrm{Pb}$ and $\mathrm{Cu}$ in lettuce, toxicity, and transport mechanisms}

The distribution of $\mathrm{Pb}$ was significantly correlated with $\mathrm{Ca}$ in lettuce seeds (correlation coefficient, $0.624^{* *}$ ) under $\mathrm{Pb}$ stress (Table $\mathrm{S} 5$ ), indicating that the transport of $\mathrm{Pb}$ might be closely related to $\mathrm{Ca}$ in lettuce since $\mathrm{Ca}^{2+}-$ permeable channels (a passive transport) is a primary pathway of Pb uptake (Trakal et al., 2015). The distribution of $\mathrm{Cu}$ was significantly correlated with $\mathrm{Fe}, \mathrm{Zn}$, and $\mathrm{Mn}$ both in seeds and seedling shoots under $\mathrm{Cu}$ stress. A major 
221

222

reason for this might be that these elements are essential elements and all use similar active and passive transport systems during uptake (Trakal et al., 2013, 2015), despite the competition exists among the uptake of $\mathrm{Cu}$ and $\mathrm{Fe}$, Zn, and Mn by plants.

Based on the $\mu$-XRF data of lettuce seeds (see Figs. 4 and 5), it was assumed that the mortality of lettuce seeds was primarily caused by the high accumulation of $\mathrm{Pb}$ and $\mathrm{Cu}$ in the radicle, resulting in cessation of radicle germination via damage to the cell division process from severe oxidative stress (Lamb et al., 2010). Previous studies have confirmed that high $\mathrm{Pb}$ and $\mathrm{Cu}$ stress impairs microtubule arrangements, damages $\mathrm{DNA}$, and causes chromosomal aberrations of cells in the roots of corn and onion (Qin et al., 2015; Sun and Luo, 2018).

A large number of $\mathrm{Cu}^{2+}$ ions can be reduced to $\mathrm{Cu}^{+}$in cells under high $\mathrm{Cu}$ stress, since cells are capable of catalyzing the formation of hydroxyl radicals (OH·) to initiate oxidative damage (Gaetke and Chow, 2003). Although copper chaperones sequester $\mathrm{Cu}$ in a non-reactive form (Himelblau and Amasino, 2000), free $\mathrm{Cu}$ ions readily oxidize thiol bonds within proteins. This causes a disruption of their structure when $\mathrm{Cu}$ exceeds a threshold value in plants (Briat and Lebrun, 1999). Lead oxidative stress (near $300 \mathrm{mg} \mathrm{L}^{-1}$ ) may also induce membrane damage to the cells of plants by producing excess ROS (Venkatachalam et al., 2017). Excess ROS can cause oxidative cell damage and even necrosis in plants due to the interaction of PTE ions with biomolecules (Yin et al., 2008). In conclusion, the toxicity of high concentrations of $\mathrm{Pb}$ and $\mathrm{Cu}$ to the radicles of lettuce seeds during germination is fatal.

Copper could be transported rapidly throughout the entire seed using both active and passive transport systems since $\mathrm{Cu}$ is an essential element for plants (Trakal et al., 2013). We discovered that the radicles of dead seeds under severe $\mathrm{Cu}$ levels extended noticeably out of the seed bodies (Fig. 5). Moreover, the mineral nutrients (e.g., $\mathrm{K}, \mathrm{Ca}, \mathrm{Fe}, \mathrm{Mn}, \mathrm{Cu}$, and $\mathrm{Zn}$ ) involved in the metabolism of lettuce seed germination are preferentially and rapidly transported to the tip of the radicle and the tip of the cotyledon (Fig. 5), where metabolism is vigorous at levels 
below the point of mortality. The radicles of dead seeds under severe Pb levels, however, barely protruded out of the seeds, while $\mathrm{Pb}, \mathrm{Fe}, \mathrm{Mn}$, and $\mathrm{Zn}$ were only concentrated in the radicles of lettuce seeds (Fig. 4). We hypothesize that cells in lettuce seeds are more sensitive to the toxicity of $\mathrm{Pb}$ than $\mathrm{Cu}$. In this scenario, the lettuce seeds died quickly under severe $\mathrm{Pb}$ levels, and there was not enough time to transport the mineral nutrient elements to the top of cotyledons, despite the fact that Fe, Mn, and $\mathrm{Zn}$ uptake uses active transport systems. The lettuce seeds died slowly under severe $\mathrm{Cu}$ levels, however, and there was enough time to germinate a radicle and transport mineral nutrients to the top of cotyledons. To our knowledge, this is the first report of spatial information on the migration and accumulation of PTEs and mineral elements in lettuce seeds. occurrence that may be related to the formation of iron plaques on the root surface of lettuce seedlings. Iron plaque easily forms on the root surface of wetland plants (Tai et al., 2018), and can significantly affect the sorption and immobilization of PTEs in the soil-plant system, even during the seedling period (Li et al., 2020). The distributions of $\mathrm{Pb}$ and $\mathrm{Cu}$ were clearly collocated with $\mathrm{Fe} / \mathrm{Mn}$ plaques in the root hair zone, primarily due to the chelation of $\mathrm{Pb}$ and $\mathrm{Cu}$. toxicity to organelles in plant cells (Sun and Luo, 2018). In future studies of the PTE toxicity mechanisms in plants, we can use TEM, synchrotron radiation-based Fourier transform infrared (SR-FTIR), and XAFS spectroscopy to identify PTE species and their binding structures with sorption sites in plant tissues.

\section{Conclusions}

This study demonstrated that lettuce plants use vacuoles and cell walls to reduce the transport of $\mathrm{Pb}$ and $\mathrm{Cu}$ through their roots as a protective mechanism. High accumulations of $\mathrm{Pb}$ and $\mathrm{Cu}$ in the radicle result in the death of lettuce seeds under severe levels of PTEs, while radicle growth of lettuce seed was easier inhibited by $\mathrm{Pb}$ at 
severe levels than $\mathrm{Cu}$. The PTE-loaded capacity that ensures food safety of $\mathrm{Pb}\left(65.1 \mathrm{mg} \mathrm{kg}^{-1}\right)$ in studied soil for

266

267

lettuce was lower than that of $\mathrm{Cu}\left(89.9 \mathrm{mg} \mathrm{kg}^{-1}\right)$, whereas the PTE-loaded capacity that limits yield and the PTEloaded capacity that kills seeds of $\mathrm{Pb}\left(997.2\right.$ and $\left.2643.5 \mathrm{mg} \mathrm{kg}^{-1}\right)$ were much higher than those of $\mathrm{Cu}(212.1$ and $525.4 \mathrm{mg} \mathrm{kg}^{-1}$ ). The health risk of $\mathrm{Pb}$ in visually healthy lettuce appeared to be higher than that of $\mathrm{Cu}$ under the same soil contamination level. We strongly recommend a strengthened food safety supervision and inspection in agricultural production to reduce the health risk of PTEs via visually healthy vegetables (with excessive PTEs content, however) intake.

\section{Declaration of Competing Interest}

The authors declare that they have no known competing financial interests or personal relationships that could have appeared to influence the work reported in this paper.

\section{Acknowledgments}

The $\mu$-XRF beam time was granted by 4W1B beamline of Beijing Synchrotron Radiation Facility, Institute of High Energy Physics (Chinese Academy of Sciences). We are indebted to all staff members of 4W1B for their support in measurements and data reduction. This work was financially supported by the National Key Research and Development Program of China (2017YFD0202101), the National Natural Science Foundation of China (21866013, 21876027, 51904079), the United Fund of Guangdong Provincial Basic and Applied Basic Research Foundation, China (2019A1515110705), the Crop Science Postgraduate Innovation Project of Hainan University Tropical Agriculture and Forestry College (ZWCX2018012, ZWCX2018013), the Ministry of Education, Youth and Sports of the Czech Republic (CZ.02.1.01/0.0/0.0/16_026/0008403), and the Special Funding for the Science and Technology Innovation Team of Foshan, China (1920001000083). 
Ali, S., Chaudhary, A., Rizwan, M., Anwar, H.T., Adrees, M., Farid, M., Irshad, M.K., Hayat, T., Anjum, S.A., 2015. Alleviation of chromium toxicity by glycinebetaine is related to elevated antioxidant enzymes and suppressed chromium uptake and oxidative stress in wheat (Triticum aestivum L.). Environ. Sci. Pollut. Res. 22, 10669-10678. https://doi.org/10.1007/ s11356-015-4193-4

292

Bandara, T., Franks, A., Xu, J., Bolan, N., Wang, H., Tang, C., 2020. Chemical and biological immobilization mechanisms of potentially toxic elements in biochar-amended soils. Crit. Rev. Environ. Sci. Technol. 50, 903-978. https://doi.org/10.1080/10643389.2019.1642832

295

Bao, S., 2000. Chemical Analysis for Agricultural Soil. China Agriculture Press, Beijing.

Briat, J.F., Lebrun, M., 1999. Plant responses to metal toxicity. Comp. R. Acad. Sci. Paris. 322, $43-54$. https://doi.org/10.1016/S0764- 4469(99)80016-X

Cai, L.M., Wang, Q.S., Luo, J., Chen, L.G., Zhu, R.L., Wang, S., Tang, C.H., 2019. Heavy metal contamination and health risk assessment for children near a large Cu-smelter in Central China. Sci. Total. Environ. 650, 725-733. https://doi.org/10.1016/j.scitotenv.2018.09.081

Calabrese, E.J., 2008. Hormesis: why it is important to toxicology and toxicologists. Environ. Toxicol. Chem. 27(7), 14511474. https://doi.org/10.1897/07-541

Chen, H., Yang, X., Wang, H., Sarkar, B., Shaheen, S.M., Gielen, G., Bolan, N., Guo, J., Che, L., Sun, H., Rinklebe, J., 2020. Animal carcass- and wood-derived biochars improved nutrient bioavailability, enzyme activity, and plant growth in metalphthalic acid ester co-contaminated soils: A trial for reclamation and improvement of degraded soils. J. Environ. Manage. 261(1), 110246. https://doi.org/10.1016/j.jenvman.2020.110246 
DEFRA and Environment Agency, 2002. Contaminations in soil: collation of toxicological data and intake values for humans,

Publication CLR9. The R\&D Dissemination Centre, WRC plc, Swindon, Wilts.

Ding, C.F., Li, X.G., Zhang, T.L., Wang, X.X., 2015. Transfer model of lead in soil-carrot (Daucus carota L.) system and food safety thresholds in soil. Environ. Toxicol. Chem. 34(9), 2078-2086. https://doi.org/10.1002/etc.3031

Dong, Y.X., Wang, X.F., Cui, X.M. 2013. Exogenous nitric oxide involved in subcellular distribution and chemical forms of $\mathrm{Cu}^{2+}$ under copper stress in tomato seedlings. J. Integr. Agr. 12(10), 1783-1790. https://doi.org/10.1016/S2095$3119(13) 60367-6$

Fang, Z., Gao, Y., Bolan, N., Shaheen, S.M., Xu, S., Wu, X., Xu, X., Hu, H., Lin, J., Zhang, F., Li, J., Rinklebe, J., Wang, H., 2020. Conversion of biological solid waste to graphene-containing biochar for water remediation: A critical review. Chem. Eng. J. 390, 124611. https://doi.org/10.1016/j.cej.2020.124611

FAOSTAT (UN Food \& Agriculture Organization, Statistics Division) Lettuce (with chicory) area harvested in $2018,2019$. Retrieved March 4, 2020. http://www.fao.org/faostat/en/\#data/QC

Ferri, R., Hashim, D., Smith, D.R., Guazzetti, S., Donna, F., Ferretti, E., Curatolo, M., Moneta, C., Beone, G.M., Lucchini, R.G., 2015. Metal contamination of home garden soils and cultivated vegetables in the province of Brescia, Italy: implications for human $\quad$ exposure. Sci. Total. $\quad$ Environ. 518-519, 517. https://doi.org/10.1016/j.scitotenv.2015.02.072

Gaetke, L.M., Chow, C.K., 2003. Copper toxicity, oxidative stress, and antioxidant nutrients. Toxicology 189(1-2), 147-163. https://doi.org/10.1016/S0300-483X(03)00159-8

Gomes, M.P., Duarte, D.M., Carneiro, M.M.L.C., Barreto, L.C., Carvalho, M., Soares, A.M., Guilherme, L.R., Garcia, Q.S., 2013. Zinc tolerance modulation in Myracrodruon urundeuva plants. Plant. Physiol. Bioch. 67, 1-6. https://doi.org/10.1016/j.plaphy.2013.02.018

Gruszecka-Kosowska, A., 2019. Potentially Harmful Element Concentrations in the Vegetables Cultivated on Arable Soils, 
with Human Health-Risk Implications. Int. J. Environ. Res. Public. Health. 16, 4053. https://doi.org/10.3390/ijerph16204053

Himelblau, E., Amasino, R.M., 2000. Delivering copper within plant cells. Curr. Opin. Plant. Biol. 3, $205-210$. https://doi.org/10.1016/S1369-5266(00)80066-7

Hou, S., Zheng, N., Tang, L., Ji, X., 2018. Effects of cadmium and copper mixtures to carrot and pakchoi under greenhouse cultivation condition. Ecotoxicol. Environ. Saf. 159, 172-181. https://doi.org/10.1016/j.ecoenv.2018.04.060

ISO, 1995. Soil quality—determination of the effects of pollutants on soil flora—part 2: effects of chemicals on the emergence of higher plants. ISO-International organization for standardization Genéve, pp 2-7.

Kabata-Pendias, A., 2011. Trace elements in soils and plants. CRC/Taylor and Francis Group, Boca Raton, FL.

Kim, M.J., Moon, Y., Tou, J.C., Mou, B., Waterland, N.L., 2016. Nutritional value, bioactive compounds and health benefits of lettuce (Lactuca sativa L.). J. Food. Compos. Anal. 49, 19-34. https://doi.org/10.1016/j.jfca.2016.03.004

Lamb, D.T., Ming, H., Megharaj, M., Naidu, R., 2010. Relative tolerance of a range of Australian native plant species and lettuce to copper, zinc, cadmium, and lead. Arch. Environ. Con. Tox. 59(3), 424-432. https://doi.org/10.1007/s00244010-9481-x

Li, J., Wang, S-L., Zhang, J., Zheng, L., Chen, D., Wu, Z., Shaheen, S.M., Rinklebe, J., Ok, Y.S., Wang, H., Wu, W., 2020. Coconut-fiber biochar reduced the bioavailability of lead but increased its translocation rate in rice plants: Elucidation of immobilization mechanisms and significance of iron plaque barrier on roots using spectroscopic techniques. J. Hazard. Mater. 389, 122117. https://doi.org/10.1016/j.jhazmat.2020.122117

Li, J., Wang, S-L., Zheng, L., Chen, D., Wu, Z., Xie, Y., Wu, W., Niazi, N.K., Ok, Y.S., Rinklebe, J., Wang, H. 2019a. Sorption of lead in soil amended with coconut fiber biochar: Geochemical and spectroscopic investigations. Geoderma. 350, 5260. https://doi.org/10.1016/j.geoderma.2019.05.008

Li, J., Zheng, L., Wang, S-L., Wu, Z., Wu, W., Niazi, N.K., Shaheen, S.M., Rinklebe, J., Bolan, N., Ok, Y.S., Wang, H., $2019 b$. 
Liu, B., Ai, S., Zhang, W., Huang, D., Zhang, Y., 2017. Assessment of the bioavailability, bioaccessibility and transfer of heavy X., Wang, H., 2017a. Effect of bamboo and rice straw biochars on the mobility and redistribution of heavy metals $(\mathrm{Cd}$, of $\mathrm{Cu}$ in rice (Oryza sativa L.) roots using synchrotron-based X-ray microfluorescence and X-ray absorption spectroscopy. https://doi.org/10.1016/j.envpol.2013.05.007

Megateli, S., Semsari, S., Couderchet, M. 2009. Toxicity and removal of heavy metals (cadmium, copper, and zinc) by Lemna

Mwamba, T.M., Li, L., Gill, R.A., Islam, F., Nawaz, A., Ali, B., Farooq, M.A., Lwalaba, J.L., Zhou, W., 2016. Differential

NAAS (National Agricultural Advisory Service) Crop Values 2014 Summary, 2015. United States Department of Agriculture. 
Rayment, G.E., Higginson, F.R., 1992. Australian Laboratory Handbook of Soil and Water Chemical Methods, Inkata, Melbourne.

Setia, R.C., Kaur, N., Setia, N., Nayyar, H., 2018. Heavy Metal Toxicity in Plants and Phytoremediation. In Crop Improvement: Strategies and Applications.

Shahid, M., Shamshad, S., Rafiq, M., Khalid, S., Bibi, I., Niazi, N.K., Dumat, C., Rashid, M.I., 2017. Chromium speciation, bioavailability, uptake, toxicity and detoxification in soil-plant system: a review. Chemosphere 178, 513-533. https://doi.org/10.1016/j.chemosphere.2017.03.074

Shahid, M., Niazi, N.K., Rinklebe, J., Bundschuh, J., Dumat, C., Pinelli, E., 2019. Trace elements-induced phytohormesis: A critical review and mechanistic interpretation. Crit. Rev. Environ. Sci. Technol. https://doi.org/10.1080/10643389.2019.1689061

387

Shu, X., Yin, L., Zhang, Q., Wang, W., 2012. Effect of Pb toxicity on leaf growth, antioxidant enzyme activities, and

Sokolova, I., Ringwood, A., Johnson, C., 2005. Tissue-specific accumulation of cadmium in subcellular compartments of

eastern oysters Crassostrea virginica Gmelin (Bivalvia: Ostreidae). Aquat. Toxicol. 74(3), 218-228. https://doi.org/10.1016/ j.aquatox.2005.05.012

Solé, V.A., Papillon, E., Cotte, M., Walter, P., Susini, J., 2007. A multiplatform code for the analysis of energy-dispersive X- 
397

398

399

400

401

402

403

404

405

406

407

408

409

410

411

413

Tai, Y., Tam, N.F., Wang, R., Yang, Y., Lin, J., Wang, J., Yang, Y., Li, L., Sun, Y., 2018. Iron plaque formation on wetland-plant roots accelerates removal of water-borne antibiotics. Plant Soil 433, 323-338. https://doi.org/10.1007/s11104-018-3843y

Trakal, L., Kodešová, R., Komárek, M., 2013. Modelling of Cd, Cu, Pb and Zn transport in metal contaminated soil and their uptake by willow (Salix $\times$ smithiana) using HYDRUS-2D program. Plant Soil 366, 433-451. https://doi.org/10.1007/s11104-012-1426-x

Trakal, L., Martínez-Fernández, D., Vítková, M., Komárek, M., 2015. Phytoextraction of Metals: Modeling Root Metal Uptake and Associated Processes. In Phytoremediation: Management of Environmental Contaminants 1, 69-83. https://doi.org/10.1007/ 978-3-319-10395-2_6

van Assche, F., Clijsters, H., 1990. Effects of metals on enzyme activity in plants. Plant Cell Environ. 13, $195-206$. https://doi.org/10.1111/j.1365-3040.1990.tb01304.x

Venkatachalam, P., Jayalakshmi, N., Geetha, N., Sahi, S.V., Sharma, N.C., Rene, E.R., Sarkar, S.K., Favas, P.J.C., 2017. Accumulation efficiency, genotoxicity and antioxidant defense mechanisms in medicinal plant acalypha indica 1. under lead stress. Chemosphere 171, 544-553. https://doi.org/10.1016/j.chemosphere.2016.12.092

Webb, B., Adeloju, S.B., 2013. Evaluation of some wet digestions methods for reliable determination of total phosphorus in Australian soils. Microchem. J. 111(14), 47-52. https://doi.org/10.1016/j.microc.2013.02.001

Wenzel, W.W., 2009. Rhizosphere processes and management in plant-assisted bioremediation (phytoremediation) of soils. Plant Soil 321, 385-408. https://doi.org/10.1007/s11104-008-9686-1

Wu, W., Li, J., Lan, T., Müller, K., Niazi, N.K., Chen, X., Xu, S., Zheng, L., Chu, Y., Li, J., Yuan, G., Wang, H., 2017. Unraveling sorption of lead in aqueous solutions by chemically modified biochar derived from coconut fiber: A microscopic and spectroscopic investigation. Sci. Total. Environ. 576, 766-774. https://doi.org/10.1016/j.scitotenv.2016.10.163 
Wu, Z., McGrouther, K., Chen, D., Wu, W., Wang, H., 2013. Subcellular Distribution of Metals within Brassica chinensis L. https://doi.org/10.1021/jf4005725

Wu, Z., Mcgrouther, K., Huang, J., Wu, P., Wu, W., Wang, H., 2014. Decomposition and the contribution of glomalin-related soil protein (GRSP) in heavy metal sequestration: field experiment. Soil Biology. Biochem. 68(1), $283-290$. https://doi.org/10.1016/ j.soilbio.2013.10.010

Xia, S., Song, Z., Jeyakumar, P., Bolan, N., Wang, H., 2020. Characteristics and applications of biochar for remediating Cr(VI)contaminated soils and wastewater. Environ. Geochem. Hlth. https://doi.org/10.1007/s10653-019-00445-w

427

Yang, D., Guo, Z., Green, I.D., Xie, D., 2016. Effect of cadmium accumulation on mineral nutrient levels in vegetable crops: potential implications for human health. Environ. Sci. Pollution. Res. 23(19), 19744-19753. https://doi.org/10.1007/ s11356-016-7186-Z

Yin, X.L., Jiang, L., Song, N.K., Yang, H., 2008. Toxic reactivity of wheat (Triticum aestivum) plants to herbicide isoproturon. J. Agr. Food. Chem. 56, 4825-4831. https://doi.org/10.1021/jf800795v

Yuan, Y., Xiang, M., Liu, C., Theng, B.K.G., 2019. Chronic impact of an accidental wastewater spill from a smelter, China: A study of health risk of heavy metal(loid)s via vegetable intake. Ecotox. Environ. Safe. 182, 109401. https://doi.org/10.1016/j.ecoenv.2019.109401

Zhang, C., Zhang, P., Mo, C., Yang, W., Li, Q., Pan, L., Lee, D.K., 2013. Cadmium uptake, chemical forms, subcellular distribution, and accumulation in Echinodorus osiris Rataj. Environ. Sci-Proc. Imp. 15(7), 1459-1465. 
440 Lead and copper concentrations ( $\mathrm{mg} \mathrm{kg}^{-1}$, DW) in the shoots and roots of lettuce

\begin{tabular}{|c|c|c|c|c|c|c|}
\hline \multirow{2}{*}{ PTE level } & \multicolumn{3}{|c|}{$\mathrm{Pb}$ treatment } & \multicolumn{3}{|c|}{$\mathrm{Cu}$ treatment } \\
\hline & Shoot & Root & $\mathrm{TF}(\%)$ & Shoot & Root & $\mathrm{TF}(\%)$ \\
\hline 0 & $5.73 \pm 0.34 d$ & $17.4 \pm 0.87 \mathrm{~d}$ & $33.1 \pm 3.6 \mathrm{a}$ & $78.0 \pm 5.85 \mathrm{~d}$ & $118.8 \pm 4.1 \mathrm{~d}$ & $65.5 \pm 2.7 \mathrm{a}$ \\
\hline 25 & $9.76 \pm 0.49 d$ & $35.7 \pm 2.14 d$ & $27.3 \pm 1.5 b$ & $152.2 \pm 17.5 c$ & $338.1 \pm 20.5 c$ & $44.9 \pm 2.4 b$ \\
\hline 50 & $56.3 \pm 4.51 c$ & $201.4 \pm 16.1 \mathrm{c}$ & $28.2 \pm 4.1 \mathrm{ab}$ & $203.4 \pm 13.6 b$ & $685.2 \pm 19.9 b$ & $29.7 \pm 1.1 \mathrm{c}$ \\
\hline 250 & $210.9 \pm 19.0 b$ & $892.7 \pm 64.5 b$ & $23.6 \pm 0.5 b$ & $299.9 \pm 23.0 \mathrm{a}$ & $2353 \pm 81.6 a$ & $12.7 \pm 0.5 \mathrm{~d}$ \\
\hline 500 & $432.7 \pm 21.6 a$ & $1789 \pm 89.5 a$ & $24.3 \pm 2.4 b$ & -- & -- & -- \\
\hline
\end{tabular}

442 ability of plants to translocate $\mathrm{Pb}$ or $\mathrm{Cu}$ from the roots to the shoots using the following equation: $\mathrm{TF}=100 \times$

$443 \mathrm{C}_{\text {shoot }} / \mathrm{C}_{\text {root, }}$, where $\mathrm{C}$ refers to the concentration of potentially toxic element (PTE) in tissues $\left(\mathrm{mg} \mathrm{kg}^{-1} \mathrm{DW}\right)$. Values

444 within a column followed by the same letter do not differ significantly (Tukey's multiple-range test, $p=0.05$; number of

445 replications per treatment $=3$ ). 

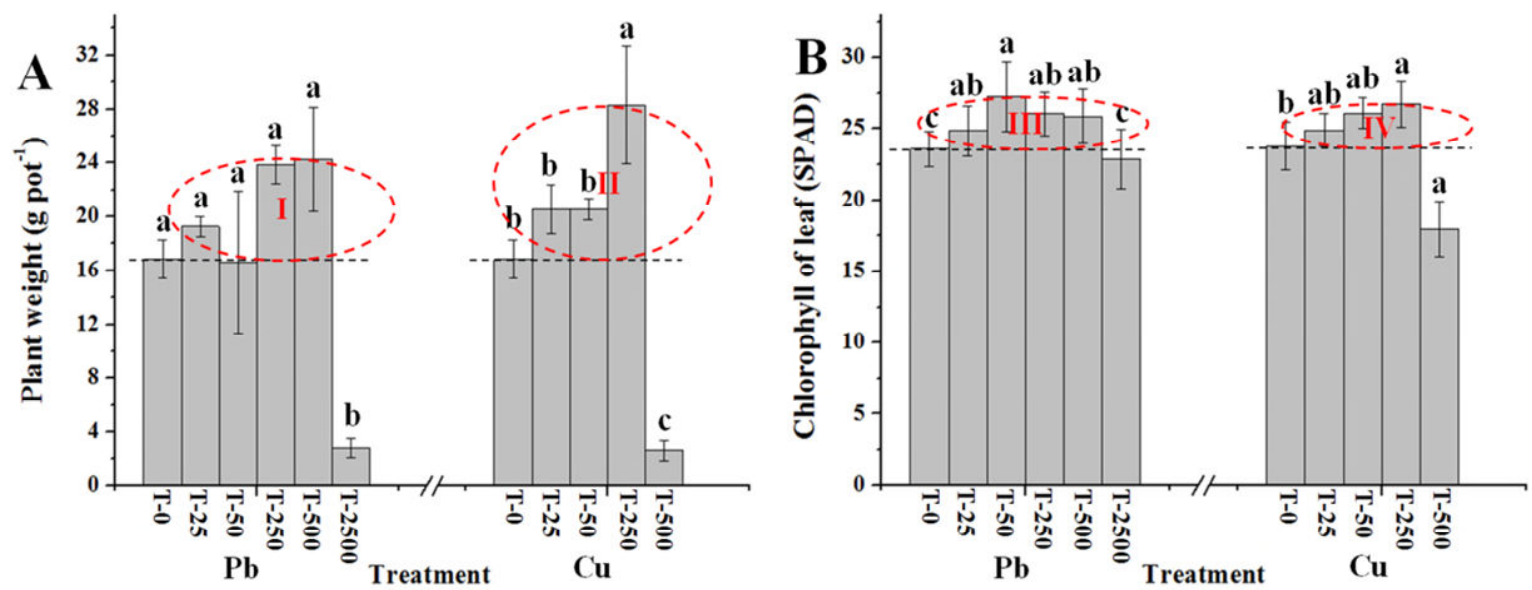

448 Fig. 1 (A) Weight of lettuce (Lactuca sativa L.) plants and (B) chlorophyll content of lettuce leaves in studied soils with

different $\mathrm{Pb}$ and $\mathrm{Cu}$ levels; regions "I," "II," "III," and "IV" indicate the area between the value of the control treatment and

the highest value, i.e., the hometic effect zone. The T-0, T-25, T-50, T-250, T-500, and T-2500 labels refer to contaminated PTE 

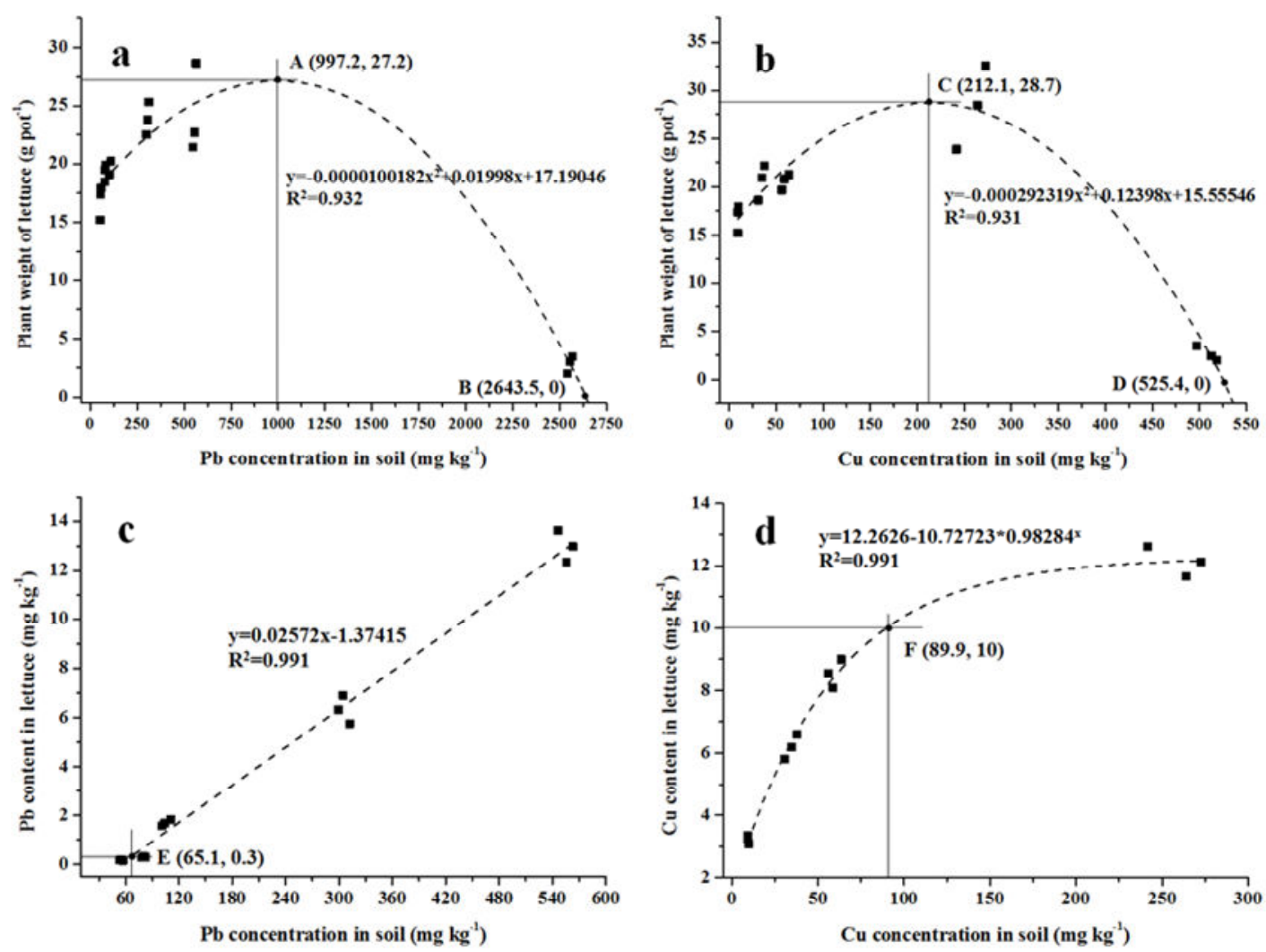

Fig. $2(\mathrm{a}-\mathrm{b})$ Lettuce plant weight with increasing $\mathrm{Pb}$ and $\mathrm{Cu}$ levels in contaminated soil, $\mathrm{A}$ and $\mathrm{B}$ show the yield decreasing

concentration and lethal concentration of $\mathrm{Pb}$ for lettuce, while $\mathrm{C}$ and $\mathrm{D}$ show the yield decreasing concentration and lethal 


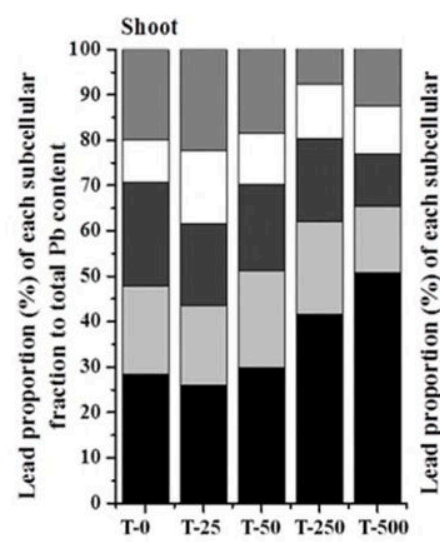

A

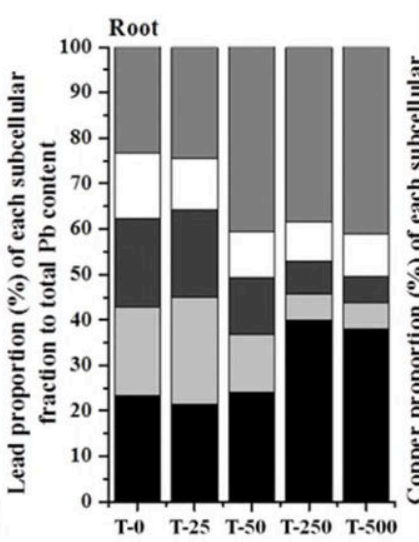

B

$\mathrm{Pb}$ treatment

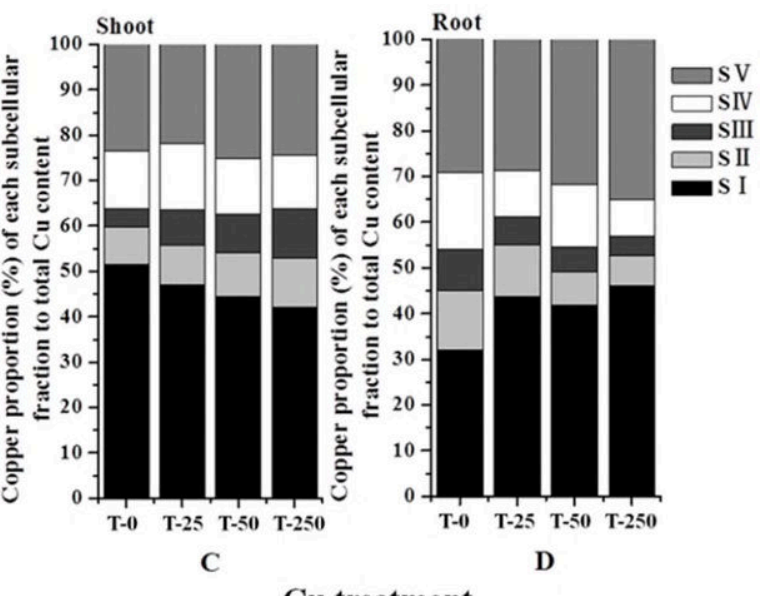

Cu treatment

Fig. 3 Subcellular proportions of $\mathrm{Pb}(\mathrm{A}$ and $\mathrm{B})$ and $\mathrm{Cu}(\mathrm{C}$ and $\mathrm{D})$ in shoots and roots of lettuce plants under different $\mathrm{Pb}$ and 

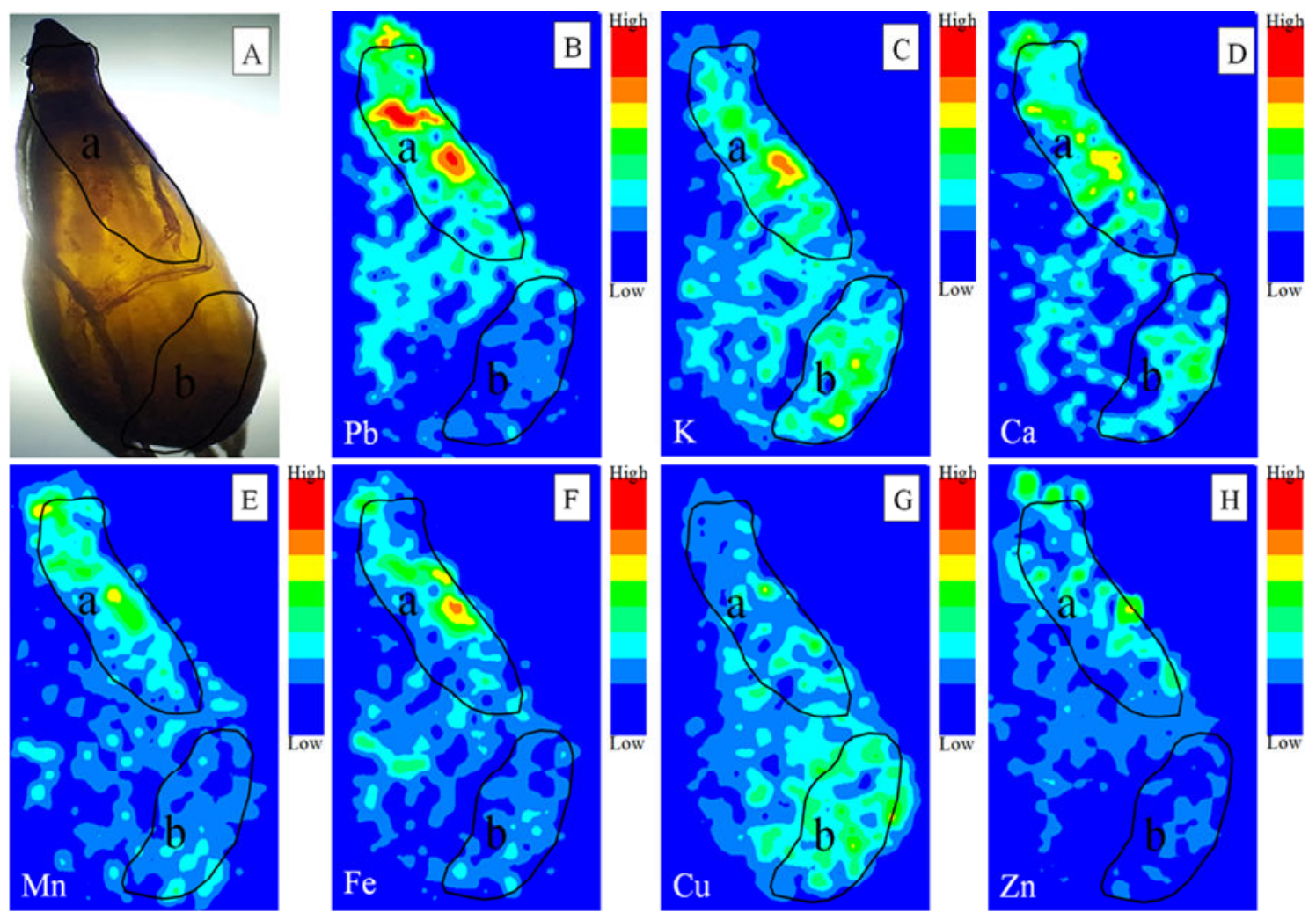

466

Fig. 4 (A) photo and (B-H) $\mu$-XRF images of $\mathrm{Pb}, \mathrm{K}, \mathrm{Ca}, \mathrm{Mn}, \mathrm{Fe}, \mathrm{Cu}$, and $\mathrm{Zn}$ distributions in longitudinal sections of dead

lettuce seeds (poisoned to death) in response to $\mathrm{Pb}$ level of $5000 \mathrm{mg} \mathrm{kg}^{-1}$ in studied soil. These seeds were collected on the 5 th 

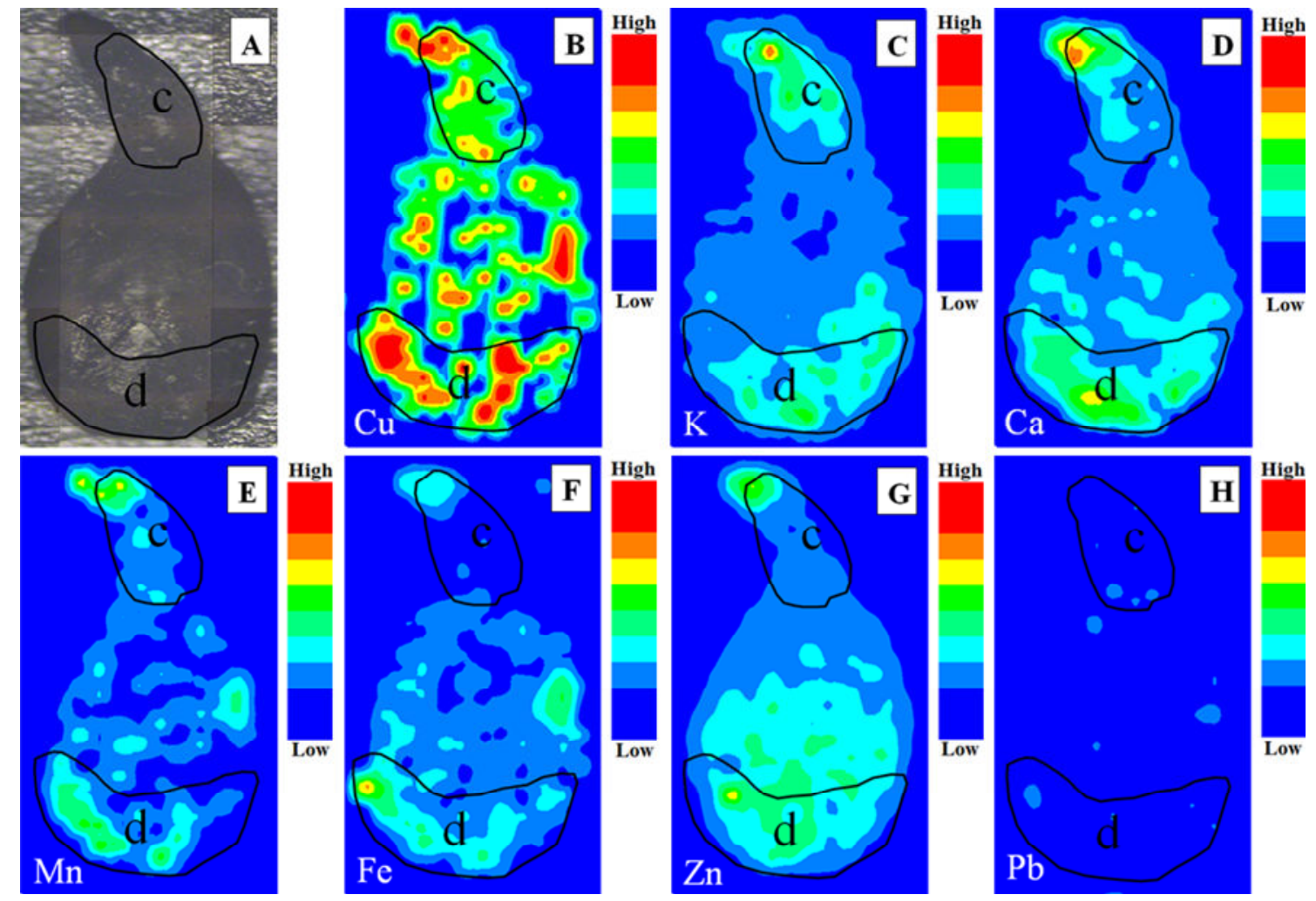

472

Fig. 5 The $\mu$-XRF images of $\mathrm{Cu}, \mathrm{K}, \mathrm{Ca}, \mathrm{Mn}, \mathrm{Fe}, \mathrm{Zn}$, and $\mathrm{Pb}$ distribution in longitudinal sections of dead lettuce seeds (poisoned

to death) in response to a $\mathrm{Cu}$ level of $2500 \mathrm{mg} \mathrm{kg}^{-1}$ in studied soil. Samples were collected on the 5th day. Higher fluorescence

intensities tend toward the red end of the color scale while lower intensities tend toward the blue. 

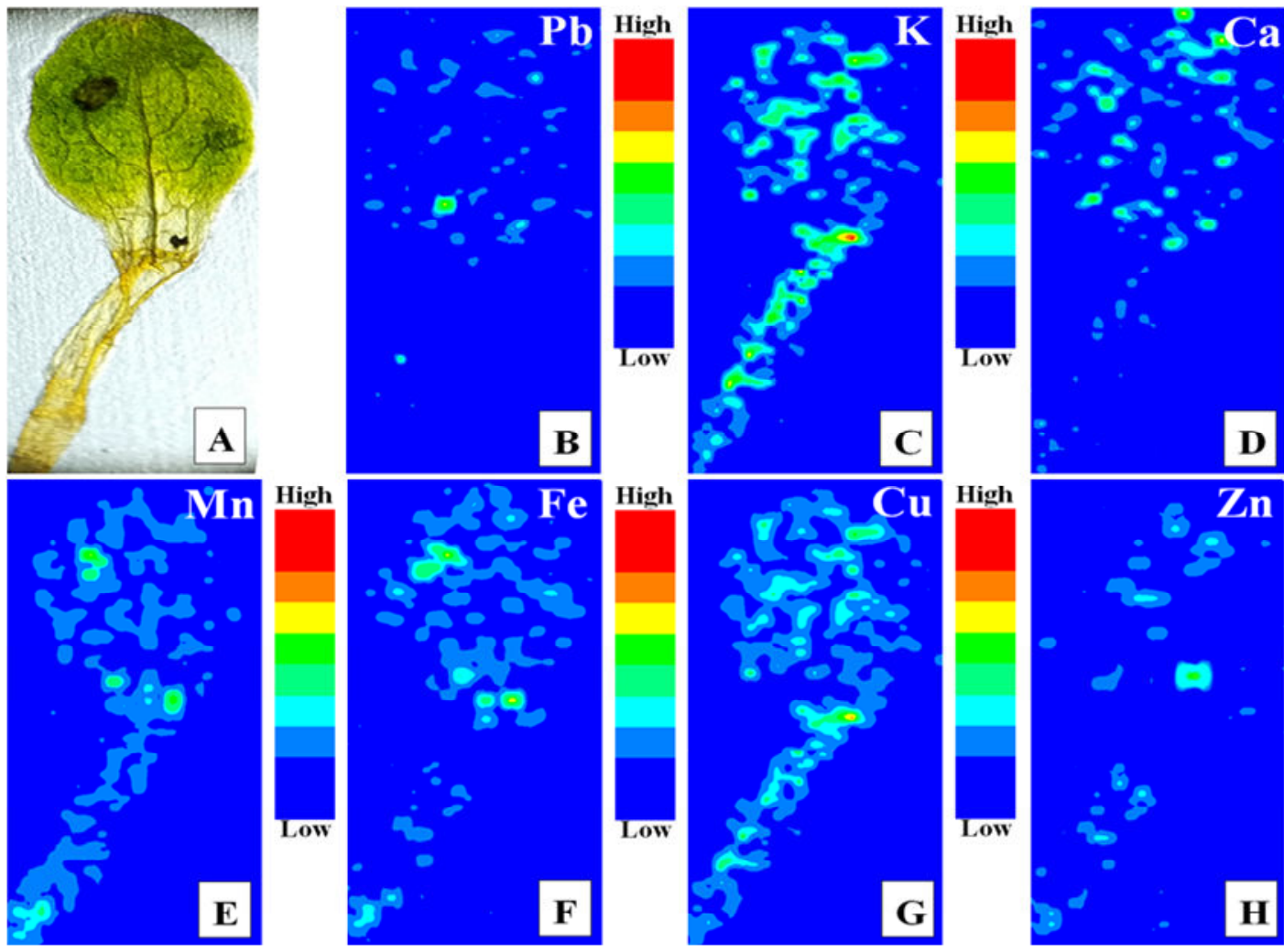

High
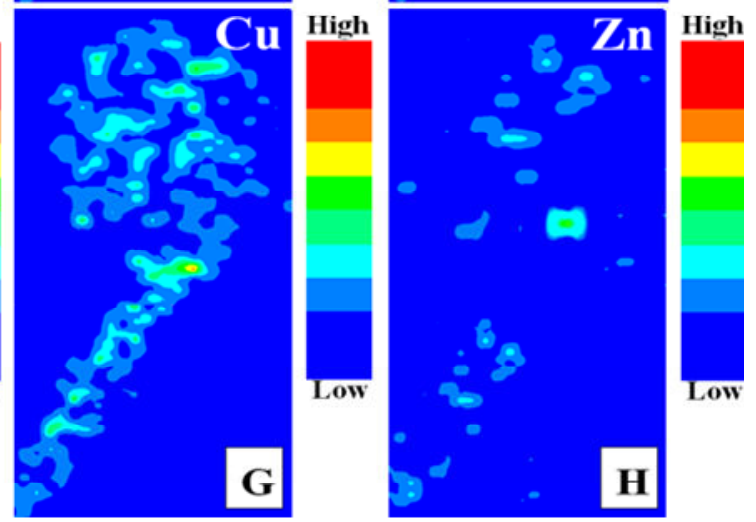

477

Fig. 6 The $\mu$-XRF images of $\mathrm{Pb}, \mathrm{K}, \mathrm{Ca}, \mathrm{Mn}, \mathrm{Fe}, \mathrm{Cu}$, and $\mathrm{Zn}$ distribution in longitudinal sections of lettuce seedling in response

to a $\mathrm{Pb}$ level of $50 \mathrm{mg} \mathrm{kg}^{-1}$ in studied soil. Samples were collected on the 5 th day. Lower fluorescence intensities tend toward

the blue end of the color scale while higher intensities tend toward the red end of the color scale.

480 

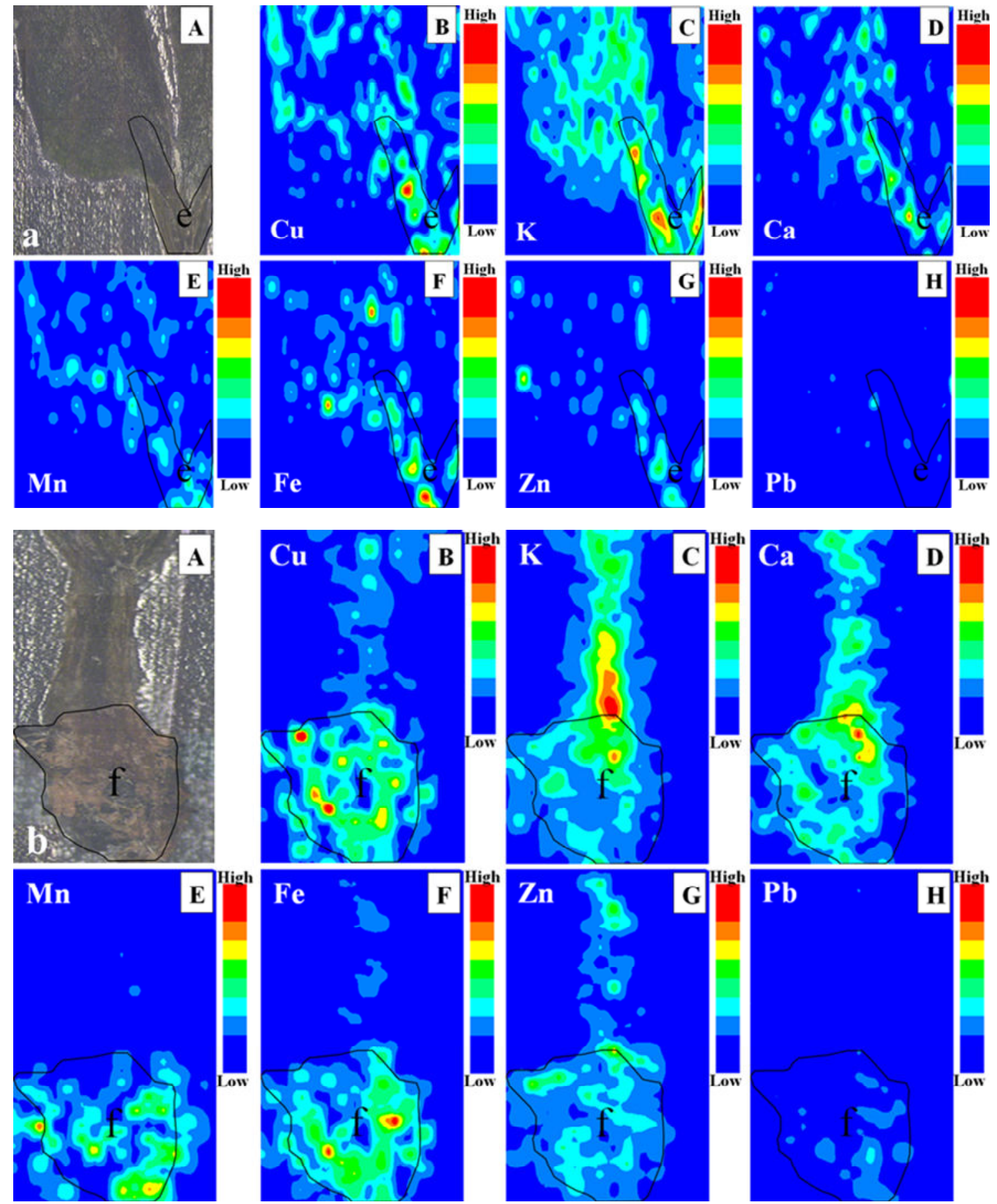

Fig. 7 The $\mu$-XRF images of $\mathrm{Cu}, \mathrm{K}, \mathrm{Ca}, \mathrm{Mn}, \mathrm{Fe}, \mathrm{Zn}$, and $\mathrm{Pb}$ distribution in longitudinal sections of lettuce seedling (a) shoots 